\title{
BANKING SUPERVISION AND EXTERNAL AUDITORS: THEORY AND EMPIRICS
}

\author{
Donato Masciandaro` Oana Peia* \\ Davide Romelli*
}

December 2019

\begin{abstract}
This paper investigates the role of external auditors in banking sector supervision from a theoretical, institutional and empirical perspective. We first present a simple principalagent framework that highlights the importance of several institutional characteristics in determining the optimal involvement of external auditors in supervision. We then construct a new index that captures the degree of involvement of external auditors in the oversight of the banking sector in 115 countries. Consistent with our theoretical arguments, we find that countries that increase the role of central banks in supervision are also more likely to involve auditors, suggesting that the added complexity of a supervisory function is likely to benefit from the expertise of an external auditor. Having experienced a financial crisis is also associated with a higher use of auditors, particularly among central banks with an increasing role in supervision, which suggests some reputational concerns of the supervisor. Finally, we show that higher audit quality is associated with an increased involvement of auditors in supervision.
\end{abstract}

Keywords: Banking Supervision, Auditing, Delegation, Economics and Law.

JEL Classification: G21, G28

^ Corresponding Author; Department of Economics and Baffi Carefin Centre, Bocconi University, Italy and SUERF; email: donato.masciandaro@unibocconi.it.

* UCD School of Economics, University College Dublin, Ireland; email: oana.peia@ucd.ie.

- Department of Economics, Trinity College Dublin; email: romellid@tcd.ie. 


\section{INTRODUCTION}

In the aftermath of the 2008 Global financial crisis, researchers and policymakers alike have pointed to the weakness of banking supervisory frameworks as one of the leading causes of the crisis (see Merrouche and Nier, 2010; Kupiec et al., 2017). An effective supervision technology ought to detect, well in advance, potential threats to the safety and soudness of the banking sector. Previous research has explored various aspects of banking regulation that can achieve such objectives, including bank capital requirements, regulatory treatments of non-performing loans and provisions or disclosure requirements. ${ }^{1}$ However, little attention has been directed towards another important aspect of financial sector oversight, i.e. the use of external auditors in the implementation of specific banking supervisory tasks.

The involvement of auditors, as private financial gatekeepers, can improve the credibility of the overall supervisory setting, as auditors generally have a beneficial influence on the behaviour of regulated firms, or banks in this case. ${ }^{2}$ For this reason, numerous initiatives on the global regulatory framework (such as the Basel Committee on Banking Supervision 2008, 2014) have recommended a tight relationship between banking supervisors and external auditors to enable an effective information exchange. The supervisor can request external auditors to perform different kinds of tasks, at times going beyond the standard audit report. However, the involvement of private actors in implementing public tasks can carry risks. For example, the supervisor can incur reputational costs given that auditors are private firms with potentially close ties to the regulated financial institutions. Similarly, the expected quality of the auditing reports defines the relative confidence with which supervisors can trust the information that auditors release. ${ }^{3}$

In this paper, we present a simple principal-agent framework that highlights the costs and benefits of involving external auditors in banking supervision. We show that the optimal involvement of external auditors depends on several institutional and country-specific factors. These include: (i) the expected benefits in terms of financial sector oversight brought on by the auditor, (ii) the quality of the auditing function and (iii) the perceived costs of auditor involvement, such as reputational concerns. We then test this hypothesis empirically by taking a positive approach and investigating whether the actual level of auditor involvement in a broad set of countries is related to the country-specific institutional characteristics underlined in our model.

To this end, we first develop a new measure that captures the level of Auditors' Involvement in Supervision, which we call the AIS Index. This new index is based on nine institutional characteristics of external auditing in the banking sector across the world, as surveyed by the

\footnotetext{
${ }^{1}$ See, among others, Merrouche and Nier (2010), Cihak et al. (2013), De Chiara et al. (2018), Aparicio et al. (2018), Anginer et al. (2018), Valencia et al. (2018), Cabrera et al. (2018), Hwa et al. (2018).

${ }^{2}$ Accounting credibility has been shown to trigger positive spillovers in various ways. For example, Alvis (2015) shows that accounting credibility can increase a firm's ability to fund its investments.

${ }^{3}$ In this respect, the 2008 Global financial crisis has not only revealed the shortcomings in the overall architecture of banking supervision, but also stressed the necessity to increase the quality of external auditing (Humphrey et al., 2009; Basel Committee on Banking Supervision, 2014; Masciandaro and Quintyn, 2014). For example, the financial turmoil has led many to wonder whether the prevailing accounting models fairly represent the banks' business models (Blankespoor et al., 2013).
} 
World Bank in 2007 and 2012. We employ the AIS Index to systematically assess the state of banking supervision in a large sample of 115 countries.

We find that countries generally adopt high levels of auditor involvement in supervision, scoring on average 7.7 out of a maximum of 9 points, in 2007 . Nonetheless, this involvement has increased even further in 2012. Countries generally require that external auditors cooperate closely with the supervisor, however less stringent requirements are in place regarding the statute and qualification of the auditors.

We then provide a series of proxies for the costs and benefits of involving auditors in supervision highlighted in our theoretical framework and investigate their relative importance in explaining the increased involvement of auditors in banking supervision observed between the two World Bank surveys. As such, our baseline model is an ordered logit model that looks at the changes in the AIS index between 2007 and 2012. Our analysis highlights several key determinants of auditors' involvement in supervision. First, we show that countries characterized by lower levels of auditor involvement in 2007 are more likely to increase it, confirming the tendency towards an ever-higher collaboration between supervisors and external auditors. Next, we find that countries that have increased the role of their central banks in supervision from 2007 to 2012 are also more likely to have a higher involvement of auditors in supervision, suggesting that the added complexity of a supervisory function is likely to benefit from the expertise of an external auditor.

We also investigate if having experienced a systemic banking crisis, as a proxy for higher reputational concerns of the supervisor, affects the likelihood of involving external auditors in supervision. We find that this is the case, but only in countries that also assigned more supervisory responsibility to their central bank, suggesting that the added complexity of a supervisory function is likely to benefit from the expertise of an external auditor. These results contribute to the literature that studies the role of financial crises in shaping supervisory and institutional settings (see Masciandaro and Romelli, 2018 and Abascal et al., 2019, among others). Lastly, in line with our theoretical model, we also show that higher audit quality, proxied by a tight oversight of auditors' actions, is associated with an increased involvement of auditors in banking sector supervision.

These results are robust to a series of sensitivity checks including various definitions of the AIS index, alternative empirical specifications and falsification strategies. To the best of our knowledge, this is the first paper to analyse the relationship between external auditing and banking supervision from a theoretical, institutional and empirical perspective. Our findings shed light on the similarities and differences in the supervisory setting around the world. Such knowledge can be particularly useful to assess the degree of convergence among national supervisory architectures in newly established communities of banking supervisors, as it is the case in the European Union (Masciandaro et al. 2011).

The remainder of the paper is structured as follows. Section 2 develops a theoretical framework to highlight the key factors that drive policymakers' choices in involving auditors in banking supervisory activities. Section 3 proposes an institutional indicator of auditor involvement in supervision and presents some descriptive statistics. Section 4 presents the empirical strategy and results, while Section 5 concludes. 


\section{OPTIMAL DESIGN OF SUPERVISORY SETTINGS}

In this section, we employ a simple principal-agent framework to study the optimal design of banking supervision involving external auditors. The supervisory technology is characterized by a mix of continuous monitoring and random auditing, where supervisors can delegate the auditing service to an independent audit agency in order to improve information quality and, at the same time, enforce supervisory settings. ${ }^{4}$

The level of delegation placed by the supervisor in the external auditing activity can, however, vary. The external auditors may be required to assist the supervisor in different ways, which can range from the drafting of audit reports on financial statements (passive collaboration), to the direct involvement in the supervisory process (active collaboration).

The external auditors' involvement in supervision can improve the effectiveness of supervisory monitoring, notwithstanding the fact that the goals of the two players - supervisor and auditor - are different. Typically, the supervisor is a public bureaucracy that serves the citizens by promoting the safety and soundness of the banking sector, while the auditor is a private firm that evaluates banks' activity.

In order to fulfill their respective mandates, both players implement actions to collect accurate and reliable information on banks. Therefore, a positive spillover can emerge if the supervisor resorts to the auditor's activity to reinforce financial gatekeeping.

However, the external auditors' involvement in supervision is not a free lunch. The use of external auditors in banking supervision might be associated with a certain degree of risk, which depends on three different factors. First, the quality of external auditing, as the usefulness of an auditor's involvement depends on the accuracy of its auditing activity. Second, the supervisory authority should compare the monetary cost of delegating audit activities to external auditors with the cost associated with employing its internal resources. In this case, the opportunity cost is likely to depend on the quantity and quality of the supervisor's staff and any benefits generated by its alternative uses. Finally, the supervisor should evaluate the reputational costs linked to the likelihood of supervisory failures when external auditors are used. External auditors may be prone to act in the benefit of bankers in order to secure future auditing contracts. ${ }^{5}$ Thus, the higher the risk of capture, the higher is the risk of supervisory failures. In this respect, economic theory highlights that when market failures are likely, private agents may lack incentives to monitor banks (Stigler, 1971).

Given these considerations, how can policymakers optimally design a supervisory framework? In what follows, we present a simple theoretical framework that highlights, the pros and cons of involving external auditors in banking sector supervision.

\subsection{The Players: Policymakers, Supervisors, Banks and External Auditors}

\footnotetext{
${ }^{4}$ Belhaj and Klimenko (2012) analyse a mix of random auditing and continuous regulator intervention. See also Singh (2013) for a legal analysis of the role of external auditors as supervisory gatekeepers in the UK. Further case studies are provided in Dewing and Russell (2010), Ojo (2012a, 2012b, and 2014).

${ }^{5}$ The relevance of this issue is striking when considering the dominant role played by the Big Four accounting firms - KPMG, PwC, Deloitte and Ernst \& Young - around the world.
} 
The set-up of the model is based on the three-layer hierarchical agency framework in Kofman and Lawarrée (1993) (see also Dalla Pellegrina and Masciandaro, 2009). In the model, a benevolent policymaker sets the rules of the game that involves three players: a supervisor, a banker, and an external auditor. ${ }^{6}$ The supervisor aims to maximize social welfare, which, in our model, implies maximizing the number of Safe and Sound Operations (hereafter, SSOs) with respect to the overall number of banking operations. ${ }^{7}$ As usual, the banking supervisor and the banker are involved in a classical principal-agent relationship: the banker has private information about the efficiency of banking operations and the supervisor lacks the time or knowledge to perfectly observe this efficiency. As such, the supervisor can employ an external auditor, who can supply additional information.

We assume that the output of an effective supervision is the number of SSOs, which is observable and verifiable by the supervisor. This number depends on two factors, which are private information of the banker: the effort, denoted by $e$, made by the banker in implementing compliance with banking regulations and a random component, denoted by $Q$, capturing the quality of the environment in which the bank operates. This "environment quality" captures the overall riskiness of banking operations, which can depend on several factors such as the business cycle or the quality of the bank's client portfolio. Hence, upon observing the number of SSOs, the supervisor cannot infer whether the large number of safe and sound operations is the result of a high effort by the banker or due to favorable business conditions, which render the overall banking environment less risky. This leads to a classical principal-agent problem between the banker and the supervisor.

For tractability, we assume that there are two states of the banking environment quality: $Q_{1}$ and $Q_{2}$, corresponding to a bad (low) and good (high) environment quality, with $Q_{2}>Q_{1}$. The bad environment $\left(Q_{1}\right)$ occurs with a probability $p$ and is characterized by a low number of $S S O s$, while the good environment $\left(Q_{2}\right)$ occurs with a probability $(1-p)$ and is conducive to a high number of safe and sound banking operations. Assuming linear functions, the number of SSOS is defined as:

$$
\tilde{X}=e+\tilde{Q}
$$

where $\tilde{X}$ denotes the random number of SSOs, $e$ the banker's effort and $\tilde{Q}$ the quality of the banking environment.

The banking supervisor compensates the banker for an effective compliance with banking regulations, through a transfer denoted by $J$. The supervisor can also punish the banker for "bad" compliance by applying a punishment $P_{B}$. As such the banker's expected payoff is represented by:

$$
E\left[\pi_{B}\right]=J-E\left[P_{B}\right]-g(e),
$$

\footnotetext{
${ }^{6}$ We assume, as usual, that players are risk neutral.

${ }^{7}$ At the same time, however, it is possible that those who set regulations - the policymaker and/or the supervisor - do not optimize social welfare, but rather maximize their own private benefits, being captured by themselves (Stigler, 1975). However, what is clear is that the policymaker and/or his/her bureaucratic agent - the supervisor - defines the rules. Therefore, we can simply assume that the policymaker is the player who evaluates the relative risks of capture (auditor capture vs. political/ supervisory capture).
} 
where $E\left[\pi_{B}\right]$ represents the bank's expected payoff, $J$ the transfer for compliance with the supervisory requirements, $E\left[P_{B}\right]$ is the expected punishment for bad compliance, which depends on the number of SSOS observed by the supervisor and its ability to infer the level of compliance (effort) of the banker. Finally, $g(e)$ is the banker's disutility of effort, which takes the usual quadratic form, given that compliance can be costly for more than one reason, $g(e)=$ $\frac{e^{2}}{2}$.

Thus, our framework assumes that a compensation scheme is in place, following the standard "carrot and stick" approach. On the one hand, the supervisor defines a rating system ( $J$ or "the carrot"), which rewards the banker for compliance. One can assume that a higher supervisory rating signals a better reputation and can be translated into monetary rewards. At the same time, the supervisor can impose a punishment fee $\left(P_{B}\right.$ or "the stick"), in case of misbehavior, i.e. when it observes a low number of SSOs. As such, the reward variable is a deterministic variable for the banker that is set by the supervisor. The punishment, on the other hand, depends on the total number of SSOS and the ability of the supervisor to infer the level of compliance of the banker. As such, this regulatory fine is conditional on the overall outcome of supervision. ${ }^{8}$

Finally, we assume that the payoff of the banker cannot drop below a minimum level, which can be set to zero. One interpretation of this participation constraint $\left(E\left[P_{B}\right]>0\right)$ is the closure of the bank: if compliance is too costly - for example in situations where the environment is too unpredictable or risky — the banker can simply interrupt her activity.

As the supervisor cannot infer the banker's effort simply from observing $\tilde{X}$, she can hire an external auditor, whose role is to produce a report that is useful to evaluate the compliance of the policies adopted by the banker. Therefore, the external auditor can help disentangle the contribution of external factors from the efforts made by the banker in affecting supervisory outcomes and to allow comparisons between banks. Employing an external auditor entails a certain cost for the supervisor, which we denote by $Z$.

The external auditor, using her professional skills can (imperfectly) detect environmental quality and, as a result, infer the level of effort exerted by the banker. The auditor observes a signal, denoted by $s$, that is positively correlated with $Q$ and produces a report to the supervisor, denoted by $\Sigma$, where $\Sigma \in\left(s_{1}, s_{2}\right)$ and $s_{2}>s_{1}$.

We assume that:

$$
\operatorname{Prob}\left[s_{1} \mid Q_{1}\right]=\operatorname{Prob}\left[s_{2} \mid Q_{2}\right]=r \quad \text { and } \quad \operatorname{Prob}\left[s_{1} \mid Q_{2}\right]=\operatorname{Prob}\left[s_{2} \mid Q_{1}\right]=1-r,
$$

where $r>\frac{1}{2}$. In other words, the probability that the auditor detects the correct environment quality is $r$, where the parameter $r$ represents the quality of the auditor's work, i.e. the precision of the signal it sends. The auditor can thus reduce the informational asymmetries existing between the supervisor and the banker. When an auditing service is delegated to an auditor, the

\footnotetext{
${ }^{8}$ Specifically, we assume that this punishment can take a value up to a maximum level $P^{\max }\left(P_{B} \leq P^{\max }\right)$. In equilibrium the punishment can take the maximum value, $P^{\max }$, without loss of generality, according to the principle of maximum deterrence (see Baron-Besanko, 1984).
} 
cheating banker faces a risk of detection, since the supervisor may ask the auditor to provide evidence of the true effort of banking compliance. The external auditor's activity thus becomes an enforcement device that can provide better quality audits, being an insider to the banking industry. However, such services cannot only be more expensive, but are also subject to the risk that the auditor and the banker might collude. ${ }^{9}$ Therefore, the cost of external audit must take into consideration the moral hazard risks associated with the behavior of private auditors. ${ }^{10}$

We can now turn to defining the supervisor's objective function. We assume that the supervisor is a benevolent civil servant that wishes to maximize the social utility, denoted by $\pi_{S} \cdot{ }^{11}$ This utility depends on the number of safe and sound banking operations (SSOS) and the compensation scheme implemented by the supervisor. Specifically, the objective function of the supervisor can be represented as follows:

$$
E\left[\pi_{S}\right]=E\left[\tilde{X}-J-Z+P_{B}\right]
$$

where $\tilde{X}$ is the random number of $S S O S$, $J$ is the compensation provided to the banker through the ranking system, $Z$ is the audit cost and $P_{B}$ is the revenue obtained by imposing punishment fees. Note that $J$ can be interpreted as the supervisor's disutility of effort in evaluating the bank and assigning it a certain ranking system, while $Z$ captures reputational costs in case of supervisory failure.

The timing of the model is presented in Figure 1 below. At the beginning of the game, the supervisor designs the incentive scheme, specifying the benefit for the banker, $J$, as a function of the efficiency of bank operations as well as a punishment, $P_{B}$. Then Nature draws the environment quality $Q$, which is observed by the banker but not the supervisor. Upon observing $Q$, the banker decides on her level of effort and output $X$ is realized. The supervisor observes $X$. If the number of SSOs is high, there is no further action. If the number of SSOs is low, the supervisor can decide to employ an external auditor. We assume the supervisor employs an auditor with probability $\gamma(X)$ in which case, she will pay the cost $Z$ and receive the auditor's report $\Sigma$. If the report concludes that the quality of the environment is likely to be high despite the observed low number of $S S O S$ (that is, with probability $1-r$ ), a punishment fee, $P_{B}$, is levied. At the end of the game, transfers (and, if applied, punishments) are realized.

\footnotetext{
${ }^{9}$ While we do not model a strategic behaviour by the auditor, it is reasonable to assume that the cost of auditing $Z$ captures not only auditing fees, but also any reputational costs for the supervisor in the case the auditor and the banker collude, and the former produces biased reports about the banker's activity.

${ }^{10}$ For simplicity, we assume that audit quality and audit costs are not correlated. However, we can relax this assumption without any loss of generality.

${ }^{11}$ The supervisor could alternatively be a bureaucrat. In this case, she is a career-concerned agent as in Alesina and Tabellini (2007).
} 


\section{Figure 1. Timing}

\begin{tabular}{|c|c|c|c|}
\hline $\mathrm{T}=0$ & $\mathrm{~T}=1$ & $\mathrm{~T}=2$ & $\mathrm{~T}=3$ \\
\hline $\begin{array}{l}\text { The supervisor offers a } \\
\text { contract to the banker } \\
\text { specifying a transfer, } \\
J \text {, and a punishment, } P_{B} \text {, } \\
\text { depending on the } \\
\text { efficiency of banking } \\
\text { operations }\end{array}$ & $\begin{array}{ll}\text { - } & \text { Nature draws } Q \\
\text { - } & \text { Banker learns } Q \\
\text { - } & \text { Banker chooses } \\
& \text { effort, } e \\
\text { - } & \text { Output, } X, \text { is } \\
& \text { produced }\end{array}$ & $\begin{array}{l}\text { Supervisor observes } \\
X \text { and may ask for } \\
\text { an external auditor's } \\
\text { report with } \\
\text { probability } \gamma(X)\end{array}$ & $\begin{array}{l}\text { - Transfers are } \\
\text { realized }\end{array}$ \\
\hline
\end{tabular}

Having defined the structure of the model, we proceed to identifying the optimal supervisory scheme.

\subsection{Supervision without auditing}

As a benchmark, we first solve the model under perfect information. In this setting, the effort of the banker is perfectly observable and it is the only determinant of her compensation scheme. There is no role for the auditor in this scenario, so $Z=0$. Similarly, as the banker's behavior is perfectly observable, the punishment, $P_{B}$ is also set to zero.

The supervisor thus chooses the optimal efforts and transfers to maximize his objective function, given the two types of environments $\left\{Q_{1}, Q_{2}\right\}$ and their corresponding probabilities $\{p,(1-p)\}$, as follows:

$$
\operatorname{Max}_{e_{1}, e_{2}} E\left[\pi_{S}\right]=p\left(Q_{1}+e_{1}-J_{1}\right)+(1-p)\left(Q_{2}+e_{2}-J_{2}\right)
$$

subject to the banker's participation (or individual rationality) constraint:

$$
\begin{aligned}
& J_{1} \geq g\left(e_{1}\right), \\
& J_{2} \geq g\left(e_{2}\right) .
\end{aligned}
$$

The banker's participation constraint implies that she must be compensated at least for the cost of her effort in each state of environment quality. Solving the maximization problem yields an optimal level of effort in each state: $e_{1}=e_{2}=1$. As such, the optimal supervisory scheme under symmetric information implies that the supervisor equalizes the marginal private cost of the bank's effort in producing SSOs with the marginal public value of the number of SSOs. At the same time, the supervisor rewards the banker just enough to make her fully compliant with the rules, independently from the quality of the environment:

$$
J\left(X_{1}\right)=J\left(X_{2}\right)=\frac{e^{2}}{2}=\frac{1}{2} .
$$


As a result, the banker's compensation is independent of the environmental quality and is set such that the banker produces the optimal effort in both states of the world, resulting in perfect compliance.

We contrast this first-best contract with the optimal allocation when there is asymmetric information and no auditor. In this case, the supervisor cannot observe the quality of the environment, nor the banker's effort. This results in a classical second-best contract. According to the revelation principle, the compensation design must satisfy the two standard incentive compatibility constraints:

$$
J_{2}-\frac{e_{2}^{2}}{2} \geq J_{1}-\frac{\left(e_{1}-\Delta Q\right)^{2}}{2} \quad \text { and } \quad J_{1}-\frac{e_{1}^{2}}{2} \geq J_{2}-\frac{\left(e_{2}-\Delta Q\right)^{2}}{2}
$$

where $\Delta Q \equiv Q_{2}-Q_{1}$ and we assume $e_{1} \geq \Delta Q$. These constraints ensure that the banker will exert the level of effort that the supervisor requires.

As usual, only the participation constraint in the low environment $\left(J_{1}=g\left(e_{1}\right)\right)$ and the incentive compatibility constraint in the high environment $\left(J_{2}-\frac{e_{2}^{2}}{2}=J_{1}-\frac{\left(e_{1}-\Delta Q\right)^{2}}{2}\right)$ are binding at the optimum (see Maskin-Riley, 1984). As a result, the supervisor's optimization problem is simply:

$$
\operatorname{Max}_{e_{1}, e_{2}, J_{1}, J_{2}} E\left[\pi_{\mathrm{S}}\right]=p\left(Q_{1}+e_{1}-J_{1}\right)+(1-p)\left(Q_{2}+e_{2}-J_{2}\right)
$$

subject to:

$$
\begin{aligned}
& J_{1}=\frac{e_{1}^{2}}{2}, \\
& J_{2}-\frac{e_{2}^{2}}{2}=J_{1}-\frac{\left(e_{1}-\Delta Q\right)^{2}}{2},
\end{aligned}
$$

which simplifies to:

$$
\operatorname{Max}_{e_{1}, e_{2}} E\left[\pi_{\mathrm{S}}\right]=p\left(Q_{1}+e_{1}-\frac{e_{1}^{2}}{2}\right)+(1-p)\left(Q_{2}+e_{2}-\frac{e_{2}^{2}}{2}-\frac{e_{1}^{2}}{2}+\frac{\left(e_{1}-\Delta Q\right)^{2}}{2}\right) .
$$

The first-order condition with respect to $e_{2}$ yields: $(1-p)\left(1-e_{2}\right)=0$, which results in the first-best level of effort, $e_{2}=1$. The level of effort in the low-quality environment is: $e_{1}=$ $1-\frac{(1-p)}{p} \Delta Q$, which is lower than the socially optimal one. Thus, the solution to the optimization problem results in a second-best contract, where the banker exerts the optimal level of effort in the high-quality environment, while in the low-quality environment, a suboptimal level of effort is exerted.

As usual, in this second-best contract, the banker enjoys an informational advantage, which gives rise to a rent when a suboptimal effort is exerted and claims are made that the low number of SSOs is due to adverse environmental conditions. 


\subsection{Supervision with auditing}

Can the outcome of regulation be improved by delegating auditing services to an external auditor? We compare the results above to an arrangement in which supervisors incur a cost $Z$ to obtain a truthful report about the state of the environment.

The timeline of the full model is presented in Figure 1 above. After Nature draws the state of the environment, the supervisor observes the number of SSOs. If the number is low, he may request the auditor, with a given probability, to produce a report $\Sigma$. If the auditor, who observes an imperfectly correlated signal about the state of the environment, concludes that the environment is likely to be good, the supervisor will infer that the lower number of SSOs is the result of insufficient compliance on the part of the banker. In this case, the banker will suffer the punishment, $P_{B}$. In other words, the fee policy is associated with the presence of the auditor. Therefore, the fee can be a proxy of the revenues associated with the auditors' involvement in supervision.

In this scenario, the supervisor will choose $e_{1}, e_{2}, J_{1}, J_{2}$ and $\gamma$ to maximize the following objective function:

$$
\operatorname{Max}_{e_{1}, e_{2}, J_{1}, J_{2}, \gamma} E\left[\pi_{\mathrm{S}}\right]=p\left\{Q_{1}+e_{1}-J_{1}+\gamma\left[(1-r) P_{B}-Z\right]\right\}+(1-p)\left\{Q_{2}+e_{2}-J_{2}\right\}
$$

subject to:

$$
\begin{aligned}
& J_{1} \geq \frac{e_{1}^{2}}{2}+\gamma(1-r) P_{B}, \\
& J_{2} \geq \frac{e_{2}^{2}}{2}, \\
& J_{2}-\frac{e_{2}^{2}}{2} \geq J_{1}-\frac{\left(e_{1}-\Delta Q\right)^{2}}{2}-\gamma r P_{B}, \\
& \gamma \leq 1,
\end{aligned}
$$

where the first two constraints are the individual rationality constraints under the low and highquality environment, while the third constraint is the incentive compatibility constraint in the high-quality environment, which, as usual, is the one binding at the optimum. Note now that constraints take into account the fact that, in the low output outcome, the bank can incur a punishment, $P_{B}$, if the supervisor chooses to employ an auditor, i.e. with probability $\gamma$. Depending on the parameters of the model, the supervisor can choose not to hire an auditor $(\gamma=0)$; always hire an auditor $(\gamma=1)$; or hire an auditor with a probability $\gamma>0$. In Appendix A, we show that at the optimum, the auditor is used, i.e. $\gamma>0$, if the following condition holds: ${ }^{12}$

$$
P_{B}>\frac{p Z}{(1-p)(2 r-1)}
$$

\footnotetext{
12 This result follows from Kofman and Lawarrée's (1993) well-known model of collusion in hierarchical agencies. See a sketch of their proof in Appendix A.
} 
In other words, an auditor is used as long as the benefits (punishment $P_{B}$ ) are greater than the weighted cost of relying on an external auditor's report. The probability of involving an external auditor in supervision is increasing in a function denoted, $\Omega$, as follows:

$$
\Omega\left(P_{B}, Z, r\right) \equiv P_{B}-\frac{p Z}{(1-p)(2 r-1)}
$$

Intuitively, this probability will depend on three structural factors: a) the expected benefits, $P_{B}$; b) the audit quality, $r$; and c) the costs, $Z$, of involving an auditor in supervision.

Straightforward comparative statics allow us to see how the probability of employing external auditors in supervision relates to each of these three factors. First, it is evident that the more a policymaker is convinced that auditors' involvement increases the credibility of the supervisory setting, the higher is the likelihood that she will adopt a policy framework that increases the role of auditors:

$$
\frac{\partial \Omega}{\partial \mathrm{P}_{\mathrm{B}}}=1>0
$$

At the same time, higher costs of involving the auditors reduce their involvement:

$$
\frac{\partial \Omega}{\partial \mathrm{Z}}=-\frac{p}{2 r(1-p)+p-1}<0
$$

Finally, auditing quality increases the optimal involvement of auditors:

$$
\frac{\partial \Omega}{\partial \mathrm{r}}=\frac{2 p Z}{4 r^{2}(1-p)+4 r(1-p)-p+1}>0
$$

Thus, the simple model in this section highlights some key institutional factors that might influence the national regulation governing the relationships between supervisors, the banking sector and auditing firms. In the model, the effectiveness of supervision depends essentially on two main drivers: the specific efforts made by banks to comply with policies and the general environment in which these institutions operate. The regulator aims to define a setting where the incentives for all the players (supervisor, bankers and auditing firms) are aligned. The crucial difficulty in addressing this is that, in general, uncertainty and industry-specific asymmetric information characterize the banking business.

We have shown that, when information is asymmetric, the effectiveness of public supervisory actions can be increased by resorting to external auditors. If bankers know that the action of public supervisors can be strengthened by involving private auditors, the credibility of the supervisory architecture will be enhanced.

Therefore, the first condition that the auditors' involvement in supervision has to match is linked to the quality of auditing reports: higher quality increases expected public gains. However, auditors' involvement is not a free lunch. Clearly, the external auditor can provide better quality audits if she is an insider in the banking industry, but, at the same time, this 
expertise can come at higher costs and a higher risk of capture, given the auditor's proximity to the industry.

Given these theoretical considerations, the probability that the supervisor engages external auditors in the banking supervision should depend on a series of country-specific factors. Specifically, the characteristics identified in our theoretical framework can be summarized as follows:

Empirical hypothesis: The probability of involving external auditors in banking sector supervision is higher (i) the larger the expected benefits in terms of financial sector oversight brought on by the auditor; (ii) the better the quality of the auditing function; (iii) the lower the (perceived) costs of auditor involvement.

We test this conjecture empirically in the next section. The first step in this analysis entails the creation of a measure of the level of involvement of auditors in banking sector supervision. We then investigate what explains changes in the degree of auditor involvement in banking sector supervision between 2007 and 2012 in a broad sample of countries.

\section{INSTITUTIONAL FRAMEWORK}

The theoretical framework presented in Section 2 predicts that external auditors' involvement in supervision depends on well-identified structural country characteristics such as auditing quality, expected reputational benefits and expected costs. To test the empirical validity of these theoretical arguments, we first build a new measure that captures the degree of auditors' involvement in supervision in a broad set of countries.

\subsection{The Auditors' Involvement in Supervision Index}

This section introduces the Auditors' Involvement in Supervision Index (AIS Index) that captures the degree to which external auditors are involved in banking supervision. To do so, we collect information from the 2007 and the 2012 Bank Regulation and Supervision Surveys of the World Bank that cover up to 142 countries (see Barth et al., 2004 and 2013). Given our research questions, we restrict our attention to the part of the survey concerned with external auditing requirements (area 5).

The construction of the index is focused around three sets of qualitative characteristics of supervisory regimes: a) auditor requirements, b) auditing requirements, and c) auditorsupervisor relationship. This information is collected through "Yes" or "No" questions, which we transform into a set of binary variables that allow us to create a composite index.

Concerning the first point on auditor requirements, we consider a) whether an audit by a professional external auditor is required for all commercial banks in each country. The obligation to employ an external auditor translates into a higher AIS index. Furthermore, the obligation of having an external auditor can be imposed with various degrees of severity. Therefore, we ask whether auditors must: b) obtain a professional certification and c) satisfy 
specific requirements. Overall, the AIS Index associated with auditor requirements ranges between 0 and 3, with higher values implying higher levels of auditors' involvement.

Secondly, we consider the legislative requirements associated with auditing standards. The auditing requirements level is higher if: a) the auditors conduct their audits in accordance with International Standards on Auditing, b) the audit report has to be publicly disclosed, c) the auditors' report on the financial statement has to be delivered to the supervisor, and contains d) information on bankers' misbehavior. Therefore, the AIS Index associated with auditing requirements goes from 0 to 4.

Finally, the AIS Index captures information regarding any kind of active collaboration between the auditors and the supervisors (auditor-supervisor relationship). This component of the index is higher if: a) the supervisor has the right to meet with the auditors without the approval of the bank, and b) the supervisor has the power to take actions against the auditors. Thus, the AIS Index associated with the auditor-supervisor relationship assumes values between 0 and 2 .

Summing up the values assigned along the three different components of the AIS Index, we compute, for each country in our sample, an overall index that captures the use of external auditors in supervision, ranging from 0 to $9 .{ }^{13}$ Table 1 shows the subset of questions from the 2007 and the 2012 Bank Regulation and Supervision Surveys of the World Bank that have been considered in the construction of the AIS Index. This table also reports the p-values of the ttest of the equality of the means between the different sub-component of the AIS index across the two versions of the Bank Regulation and Supervision Survey. The tests reject the null hypothesis of equality for all the points regarding the auditing requirements, as well as on the power of the supervisor to take actions against the external auditors, suggesting that significant changes took place between the two surveys. Appendix Table B.1 provides information on the list of analyzed countries and the level of the AIS Index in 2007 and 2012.

\footnotetext{
${ }^{13}$ A larger set of information is available in the latest version of the database. However, in order to be able to compare the 2012 measure with the 2007 one, we focus our attention on the subset of variables that are available in both surveys.
} 
Table 1: The AIS Index

\begin{tabular}{|c|c|c|c|c|c|}
\hline & & \multirow[t]{2}{*}{ Coding } & \multicolumn{2}{|c|}{ Yes $(\%)$} & \multirow[t]{2}{*}{ p-Value } \\
\hline & & & 2007 & 2012 & \\
\hline \multicolumn{6}{|c|}{ Auditor requirements } \\
\hline 1) & $\begin{array}{l}\text { Is an audit by a professional external auditor required for all commercial } \\
\text { banks in your jurisdiction? }\end{array}$ & Yes: 1 ; No: 0 & 98 & 99 & 0.55 \\
\hline 2) & $\begin{array}{l}\text { Does the external auditor have to obtain a professional certification or } \\
\text { pass a specific exam to qualify as such? }\end{array}$ & Yes: 1 ; No: 0 & 97 & 97 & 0.74 \\
\hline 3) & $\begin{array}{l}\text { Are specific requirements for the extent or nature of the audit spelled } \\
\text { out? }\end{array}$ & Yes: 1 ; No: 0 & 80 & 83 & 0.60 \\
\hline \multicolumn{6}{|c|}{ Auditing requirements } \\
\hline 4) & $\begin{array}{l}\text { Do laws or regulations require auditors to conduct their audits in } \\
\text { accordance with International Standards on Auditing (ISA)? }\end{array}$ & Yes: 1 ; No: 0 & 92 & 83 & $0.05^{*}$ \\
\hline 5) & $\begin{array}{l}\text { Is the audit report on the financial statements of a bank required to be } \\
\text { publicly disclosed together with these financial statements? }\end{array}$ & Yes: 1 ; No: 0 & 74 & 90 & $0.02 * *$ \\
\hline 6) & $\begin{array}{l}\text { Do supervisors receive a copy of the auditor's report on the financial } \\
\text { statements }\end{array}$ & Yes: 1 ; No: 0 & 97 & 100 & $0.08^{*}$ \\
\hline 7) & $\begin{array}{l}\text { Are auditors required to communicate directly to the supervisory agency } \\
\text { any presumed involvement of bank directors or senior managers in illicit } \\
\text { activities, fraud, or insider abuse? }\end{array}$ & Yes: 1; No: 0 & 77 & 88 & $0.07^{*}$ \\
\hline \multicolumn{6}{|c|}{ Auditor-supervisor relationship } \\
\hline 8) & $\begin{array}{l}\text { Does the banking supervisor have the right to meet with the external } \\
\text { auditors and discuss their report without the approval of the bank? }\end{array}$ & Yes: 1; No: 0 & 91 & 94 & 0.50 \\
\hline 9) & $\begin{array}{l}\text { In cases where the supervisor identifies that the bank has received an } \\
\text { inadequate audit, does the supervisor have the powers to take actions } \\
\text { against the external auditor }\end{array}$ & Yes: 1 ; No: 0 & 74 & 79 & $0.05^{*}$ \\
\hline
\end{tabular}

Note: Table shows the set of questions used for the construction of the AIS Index together with the coding rules and the percentage of positive answers to each question in both the 2007 and the 2012 surveys. The p-values are those of a t-test of the equality of means between these two versions of the Bank Regulation and Supervision Survey. * ** denote significance at 10 and $5 \%$ levels, respectively.

\subsection{Auditors' Involvement in Supervision: an overview}

Employing the newly created AIS Index, we provide an overview of the state of auditors' involvement in supervision around the world. In particular, we focus on the pre and post Global financial crisis period, using the latest two versions (2007 and 2012) of the Bank Regulation and Supervision Survey of the World Bank, available in both periods for a maximum of 115 countries.

Overall, the mean level of the 2012 AIS Index is equal to 8, out of a theoretical maximum of 9 , while its mean value was of 7.7 in 2007 . Figure 2 shows the distribution of the AIS Index and suggests a clustering of countries around the medium-to-high levels of external auditors' involvement in banking supervision in both surveys. In addition, it is worthwhile noticing that, in $2007,68 \%$ of the countries in our sample were characterized by an AIS Index that ranged between 8 and 9, and this percentage increased to $75 \%$ as of 2012 . 
Figure 2: The AIS Index (\% distribution)

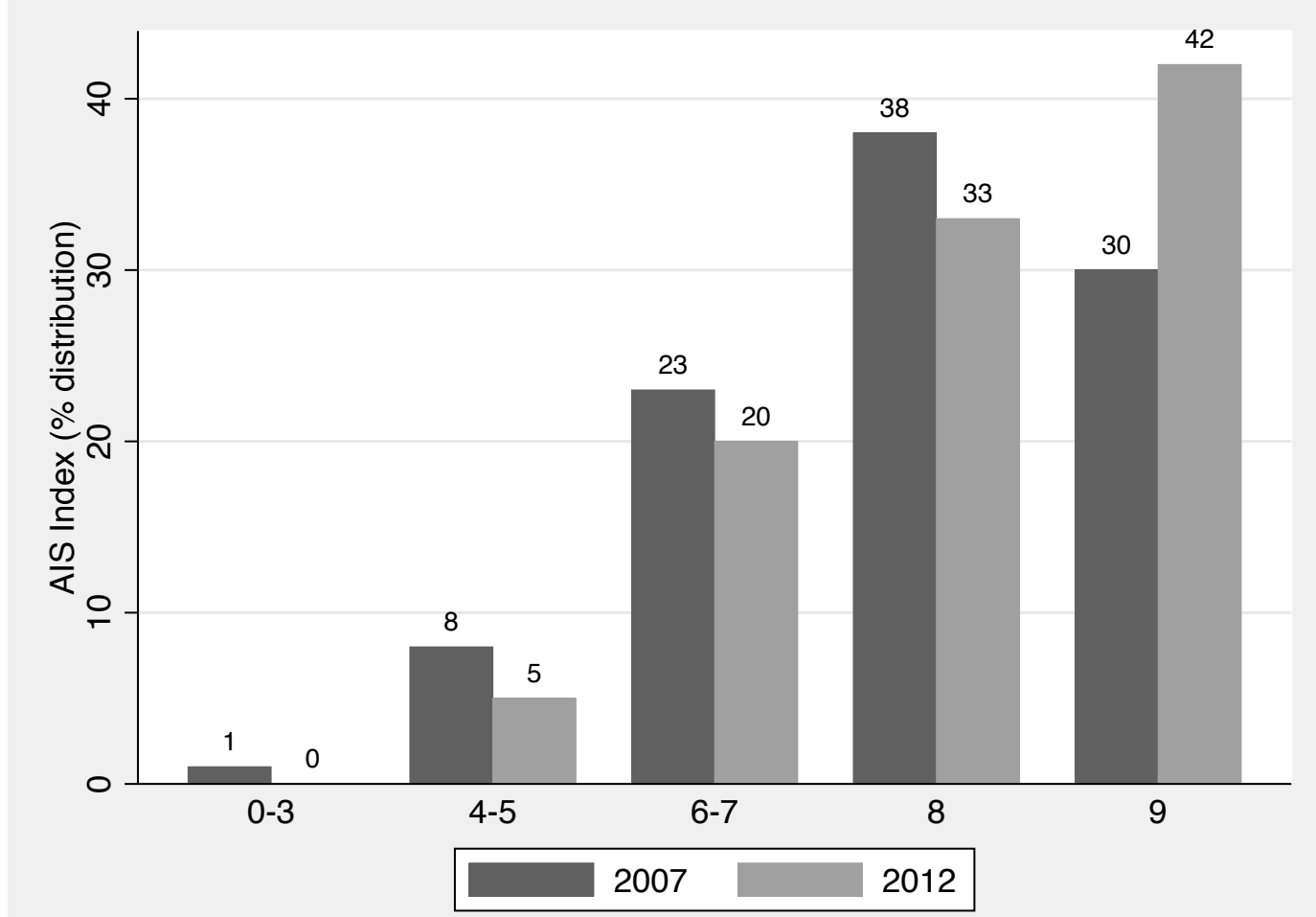

Note: Figure shows the distribution across countries of the degree of auditors' involvement in supervision in 2007 as compared to 2012, using the Auditors' Involvement in Supervision index (AIS Index) constructed in this paper.

Similar evidence is obtained when looking at the three sub-indices of the AIS Index, presented in Figure 3. The average value of the auditor requirements indicator in 2012 is 2.8 (out of 3 , i.e. $93 \%$ ), while the median value is 3 . The average value of the indicator on auditing requirements is equal to 3.6 (out of 4, i.e. $90 \%$ ), with a median level of 4 . Finally, the indicator of auditor-supervisor relationship totalizes an average of 1.6 (out of 2, i.e. $80 \%$ ) and its median value is equal to 2 . These statistics suggest an overall high involvement of external auditors in supervision with lower values only in terms of auditor requirements. 
Figure 3: Percentage of the AIS Index by Sub-indices

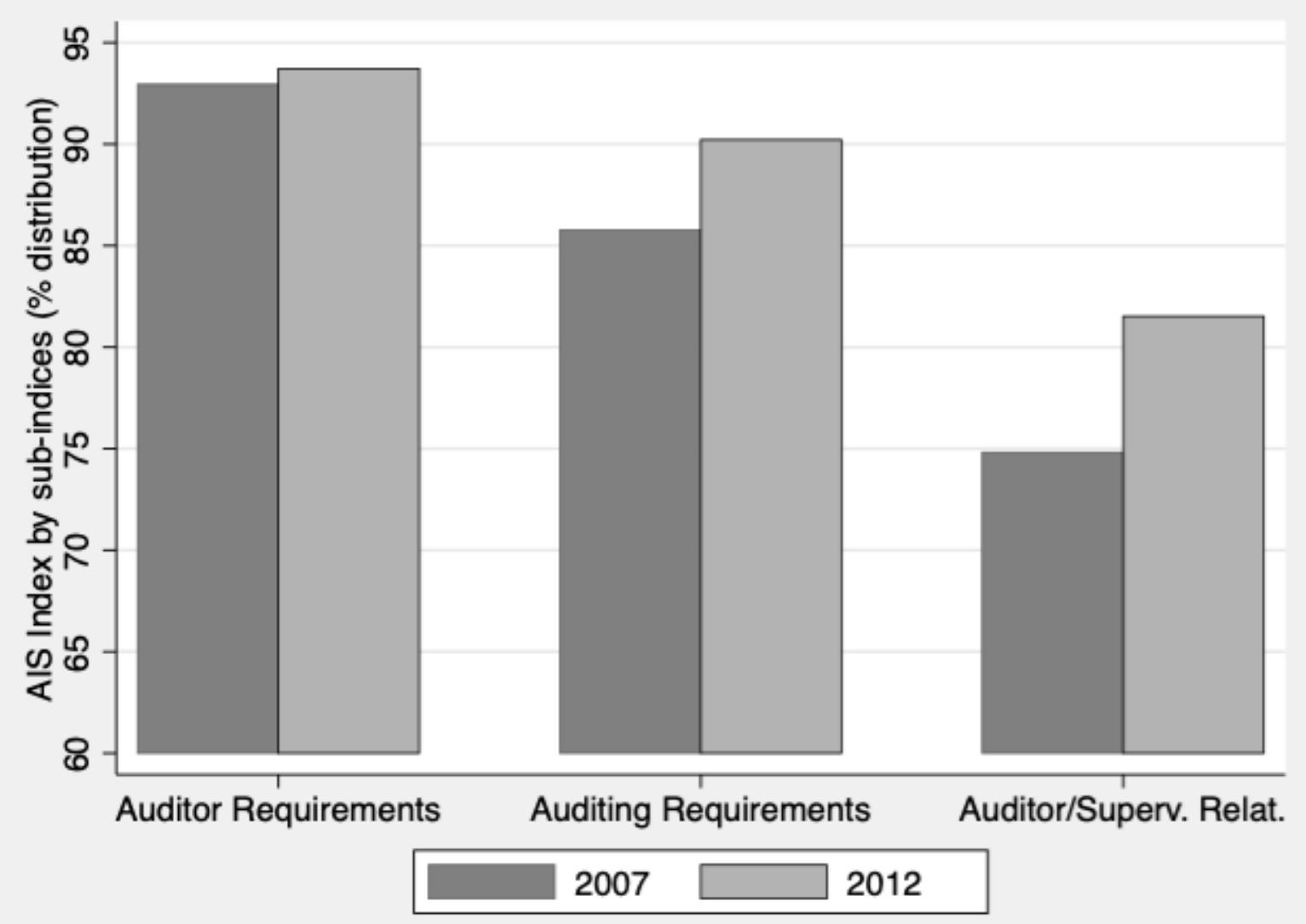

Note: This Figure summarizes the percentage value of the 3 components of the AIS Index in 2007 as compared to 2012.

Moreover, given that the two surveys used to build the AIS Index were conducted before and after the 2008 Global financial crisis, we also look at whether significant difference in the evolution of this index are present in crisis as compared to non-crisis countries. A number of recent studies have pointed to the weakness of supervisory frameworks as one of the leading causes of the 2008 Global financial crisis (see, among others, Merrouche and Nier, 2010). In particular, Cihak et al. (2013) provide new evidence on regulatory and supervisory practices around the world in the context of this crisis. They highlight that countries experiencing a crisis were characterized by a systematically less stringent regulatory environment, in particular with regards to capital and disclosure requirements.

As the presence of an external auditor is likely to be associated with a more stringent supervisory setting, it is interesting to look at whether countries that experienced a crisis were also characterized by lower levels of the AIS Index as compared to non-crisis countries. We consider as crisis countries those that experienced a systemic and/or borderline banking crisis in 2007-08, as classified by Laeven and Valencia (2013).

Figure 4 shows a comparison between the average AIS Index of crisis versus non-crisis countries in 2007 and 2012. This figure shows that crisis countries were, on average, characterized by a slightly lower external auditor involvement in supervision prior to 2007, although the difference is not statistically significant at conventional levels. In addition, both groups of countries experienced an increase in the AIS Index between 2007 and 2012. 
Figure 4: Average AIS Index for Crisis and Non-Crisis Countries (2007 vs 2012)

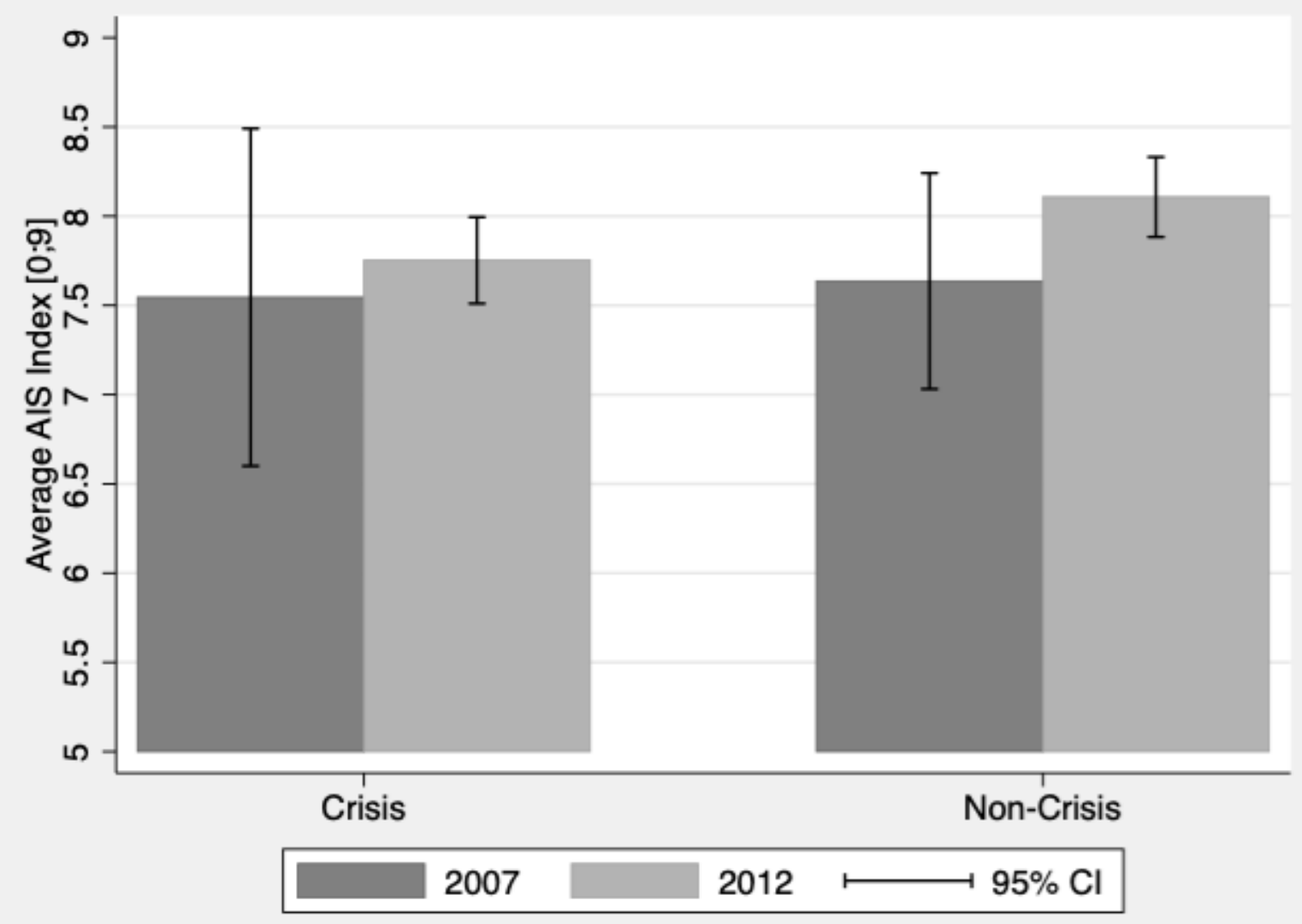

Note: Figure shows the average AIS Index in 2007 as compared to 2012, computed for crisis and non-crisis countries. $95 \%$ confidence intervals are included.

One potential explanation for this increase might be associated with the fact that following a financial crisis the reputational concerns of supervisors increased, which our model suggests will lead to a higher probability of involving external auditors in supervision. Thus, Figure 4 points to potential changes in policy preferences regarding the arms-length relationship between private gatekeepers and banking supervisors following episodes of systemic financial crises, which is one hypothesis we explore in the next section.

\section{EMPIRICS}

The theoretical framework in Section 2 identified a series of institutional characteristics that might influence the choice of involving auditors in banking sector supervision. In this section, we test these predictions empirically by looking at the changes in the AIS index over time. Specifically, we assume that legislative reforms that require a higher level of auditor involvement in supervision (higher values of the AIS index) are related to the same set of factors that have been shown to determine the equilibrium probability of employing an external auditor. Recall that these factors relate to: a) the expected benefits for the supervisor; b) the audit quality and c) the costs of involving an auditor in supervision.

Formally, the baseline model tested is as follows: 


$$
\begin{aligned}
\Delta A I S_{i, 2012}= & \beta_{1} A I S_{i, 2007}+\beta_{2} \Delta \text { Supervisory } \text { practices }_{i}+ \\
& \beta_{3} \Delta \text { Central Bank as Supervisor }{ }_{i}+\beta_{4} \text { Crisis }_{i}+\beta_{5}{ }^{\prime} X+\epsilon_{i}
\end{aligned}
$$

where $\Delta A I S_{i, 2012}$ is the change in the AIS Index between 2007 and 2012 in country $i ; A I S_{i, 2007}$ is the level of the AIS index in 2007; $\Delta$ Supervisory practices ${ }_{i}$ captures changes in overall supervisory practices; $\Delta$ Central Bank as Supervisor ${ }_{i}$ captures the changes in the degree of central bank involvement in banking and financial sector supervision, respectively. Crisis S $_{i}$ is a dummy that takes the value one for countries experiencing a systemic banking crisis as defined in Laeven and Valencia (2013) over the period 2007-2011. Finally, $X$ is a vector of proxies for other institutional factors suggested by the theoretical framework in Section 2. Given the discrete, ordinal nature of the AIS Index, the baseline estimation uses an ordered logit model that allows for multiple discrete outcomes to be ranked.

We include the lagged value of the AIS index to capture the fact that countries characterized by higher values of this index in 2007 might have smaller room to improve their degree of external auditors' involvement in supervision. Similarly, we include a measure of changes in broader supervisory practices from 2007 to 2012, proxied by the index proposed in Cihak et al. (2013). $\Delta$ Supervisory practices captures the fact that reforms in auditor involvement are likely to take place alongside other reforms in the supervisory structure of a country. These first two covariates capture important features of institutional reform processes suggested by a growing literature, namely that reforms are strongly path dependent and occur together with other institutional changes (see also, Abiad and Mody, 2005, Giuliano et al., 2013, Gokmen et al, 2017, Masciandaro and Romelli, 2018 and Romelli, 2018).

Next, we control for the expected benefits and potential costs for the supervisor of involving auditors in supervision. To do so, we first note that in $72 \%$ of countries in our sample, the central bank is the main supervisor of either the banking or the entire financial sector. Our hypothesis is that, if the supervisory role of the central bank is extended, i.e. it becomes more involved in supervision, the expected benefits of involving external auditors also increase. This is because financial supervision has not traditionally been the main role of central banks and, as such, the added complexity of a supervisory function is likely to benefit from the expertise of an external auditor. To capture changes in the role of the central bank in financial supervision, we employ two indices constructed by Masciandaro and Romelli (2018). The first, is a dummy variable that takes the value of one if the central bank is involved in banking supervision, while the second is an index that captures the degree of central bank responsibility in supervising the entire financial sectors, i.e. the banking, insurance and financial markets. We control for the change in these variables between 2007 and 2012 to capture an increasing role of central banks in supervision.

Our main proxy for the potential costs of involving an auditor in supervision is an indicator variable for countries that have experienced a banking crisis during the period considered. As banking crises are often seen as a supervisory failure, supervisors in these countries might face higher reputational costs after the crisis and our model in Section 2 suggests this should affect the probability of involving auditors in supervision. 
Finally, vector $X$ includes other proxies for the institutional characteristics suggested by our theoretical framework to affect the probability of involving external auditors in supervision. Specifically, the benefits of involving external auditors in supervision should be higher in countries with more developed credit markets that entail a more complex supervisory function. Similarly, involving external auditors should yield higher benefits in environments where information asymmetries are higher. Djankov et al. (2007) collect data on the degree of information sharing in a large set of countries and argue that countries that have public credit registries as well as private credit bureaus are likely to be characterized by less information asymmetries. They also show that this institutional setting is associated with a higher financial sector development. We thus include a measure of the share of private credit to GDP to capture the degree of credit market development and a dummy variable for the presence of public credit registries as a proxy of information asymmetries in the country. We employ these variables with a lag, i.e., use their value in 2011.

We have also argued that the benefits of including an auditor also increase with audit quality. As audit quality is difficult to quantify, we include several proxies for this factor. First, we consider a measure of regulatory quality to capture the overall regulatory environment in a country. Regulatory Quality captures perceptions of the ability of the government to formulate and implement sound policies and regulations that permit and promote private sector development (see Kaufmann et al., 2010). We also control for the number of actions taken by the supervisor against banks and auditors, respectively. This data is obtained from the 2012 Bank Regulation and Supervision Survey of the World Bank. This variable not only suggests a tight regulatory environment but can also be considered a good proxy for audit quality, as external auditors in these countries are less likely to collude with the banking sector. We also include a measure of the number of the ten biggest banks supervised by the big four auditing companies (Big4), as the higher audit standards of these international auditors can also suggest a higher overall audit quality.

Finally, we also control for the level of GDP per capita as a proxy for economic development and a country's legal origin, which has been shown to be one of the most important determinants of the legal environment and investor protection in a country. The Common Law Legal Origin is a dummy variable that takes the value of one in countries characterized by a common law legal system. ${ }^{14}$

\subsection{Main results}

The results from the baseline specification in Eq. (11) are presented in Table 2. We control for a status quo bias in all specifications by including past levels of the index and a measure of overall changes in supervisory framework following Cihak et al. (2013). In line with previous literature, we find that status quo matters as countries with a lower level of the AIS Index have a higher likelihood of increasing the involvement of external auditors in supervision. At the

\footnotetext{
${ }^{14}$ All explanatory variables considered are detailed in Appendix Table D.1. Due to data availability for these covariates, the results of the empirical analysis section focus on a smaller sample of countries. However, Appendix Table D. 2 shows that the distribution of changes in the AIS Index is similar between the full sample and this restricted sample of countries.
} 
same time, reforms in auditor involvement are more likely when overall supervisory practices also change, suggesting reforms processes come in waves.

Table 2: Reforms in the involvements of auditors in supervision: ordered logit estimates

(1)

(2)

$-0.7504 * * *$

(0.182)

AIS Index (2007)

$\Delta$ Supervisory practices

$0.3425^{* *}$

$(0.153)$

$\Delta$ Central Bank as

Supervisor

$\Delta$ Central Bank as Financial

Sector Supervisor

Financial Crisis

Regulatory Quality

Actions vs Banks

Actions vs Auditors

Big4

Public Credit Registry

Private credit to GDP

GDP per capita

Common Law Legal Origin

(0.211)

$-0.6414^{*}$

(0.341)
(3)

(4)

(5)

(6)

$1.4216^{* * *} \quad 1.5626 * * * \quad 1.8014 * * *$

(0.247)

$(0.337)$

$-0.5711$

$-0.8497$

$0.2783 * * *$

$0.3114 * *$

$0.4625 * * *$

(0.105)

(0.129)

(0.156)

$-0.5268$

$-0.1426$

$(0.377)$

(0.596)

(0.393)

(0.611)

$-0.1203 \quad-0.2881$

(0.212)

$(0.330)$

$-0.0006$

0.0001

(0.001)

(0.001)

$0.0314 * * *$

$0.0337 * * *$

(0.011)

(0.011)

0.0814

$0.1205^{*}$

(0.061)

(0.066)

0.1719

(0.383)

0.0024

$-0.0195$

$-0.1361$

$(0.211)$

(0.340)

$-0.0008$

$-0.0003$

(0.001)

(0.001)

$0.0294 * * *$

(0.011)

$0.0310^{* * *}$

0.0756

(0.011)

(0.084)

0.1148

(0.078)

$-0.0315$

(0.503)

0.0001

(0.004)

0.0000

$(0.000)$

0.6481

$(0.000)$

(0.460)

\begin{tabular}{lcccccc}
\hline Pseudo R-squared & 0.22 & 0.24 & 0.22 & 0.24 & 0.27 & 0.31 \\
Observations & 85 & 78 & 72 & 55 & 52 & 48 \\
\hline
\end{tabular}

The dependent variable is $\Delta$ AIS Index, i.e. the change in the AIS Index between 2007 and 2012. AIS Index (2007) is the degree of external auditors' involvement in supervision in 2007. $\Delta$ Central Bank as Supervisor / Central Bank as Financial Sector Supervisor captures the change in the degree of central bank involvement in banking sector and financial sector supervision, respectively between 2007 and 2012. Financial crisis is a dummy that takes the value one for countries experiencing a systemic banking crisis between 2007 and 2012. $\Delta$ Supervisory Practices captures the changes in supervisory practices adopted by a country in 2012 as compared to 2007. Regulatory Quality captures perceptions of the ability of the government to formulate and implement sound policies and regulations that permit and promote private sector development. Actions vs Banks/Auditors provides information on the number of actions that have been taken by the supervisor in the period 2006-2010 against banks/auditors. Big4 is a measure of the number of the ten biggest banks supervised by the big four auditing companies in the country. Common Law Legal Origin is a variable for common law countries. Public Credit Registry is a dummy for the presence of public credit registries in 2011 . Robust standard errors in parentheses. ${ }^{* * *}$ denotes significance at a $1 \%$ level, $* *$ denotes significance at a $5 \%$ level, * denotes significance at a $10 \%$ level.

Next, we control for the benefits of involving auditors in supervision by looking at countries where central banks have an increased role in supervision. This is captured by the $\Delta$ Central Bank as Supervisor variable in columns (1)-(3) and ACentral Bank as Financial Sector Supervisor variable in columns (4)-(6). All coefficients are positive and statistically significant, suggesting that countries that have assigned supervisory powers to their central bank have a higher likelihood of increasing the involvement of auditors in supervision. Therefore, reforms 
in the auditors' involvement in supervision are more likely to happen when the supervisory tasks of the central bank increase, i.e. when the benefits of delegating audit to an external auditor are likely to be larger. At the same time, we find little evidence that reputational concerns of a supervisor as proxied by the crisis dummy is correlated with the decision to appoint an external auditor.

Apart from these baseline covariates, columns (2) and (5) add a series of proxies for audit quality. Specifically, we control for a measure of regulatory quality proxied by the number of punishments undertaken by supervisors against banks (Actions vs Banks) and auditors (Actions vs Auditors). We also include a measure of the number of the ten biggest banks supervised by the big four auditing companies (Big4). Of these additional controls, only the Actions vs Auditors is robustly associated with an increased involvement of auditors in supervision. As a higher number of actions against auditors is likely to capture a better audit quality, this result supports our theoretical argument in Section 2.

Finally, columns (3) and (6) add the share of private credit to GDP to capture the degree of credit market development and a dummy variable for the presence of public credit registries as a proxy of information asymmetries in the country. These columns also control for a country's legal origin and GDP per capita. None of these additional co-variates are robustly correlated to the probability of reforming the degree of auditors' involvement in supervision. ${ }^{15}$

Overall, this first set of results suggests that supervisors are more likely to involve auditors when the benefits of doing so are higher, i.e. when central banks are more involved in supervision or when the audit quality is high. Reputational costs proxied by past systemic banking crises seem to matter less. In the next sub-sections, we test the robustness of these results to different variable definitions and empirical specifications.

\subsection{Principal Component Analysis}

In its current form, the index of external auditors' involvement in supervision assigns an equal weight to each of its components and disregards the actual contribution of each variable in explaining the overall variation of the index. Principal component analysis can be helpful in this context. Specifically, in this section, we employ a principal component analysis to extract the weight to assign to each component of the index given their importance in the variation of the overall index. Once we have extracted these weights, we re-compute the AIS Index accordingly.

Table 3 repeats the same econometric exercise presented in Table 2 by replacing both the dependent variable, $\triangle A I S$ Index, and its lagged level with the recomputed index using the weights extracted from the principal component analysis. The results from these new estimations are similar to those in Table 2 and confirm the importance of status quo, central bank involvement in banking and financial supervision and audit quality in explaining the changes in the AIS index from 2007 to 2012.

15 One concern is that some of the institutional characteristics we include do not vary significantly over time. We check the robustness of our results by solely focusing on the sub-set of institutional variables that have changed between 2007 and 2012. These results are presented in Appendix Table D.1 and are qualitatively similar. 
Table 3: Drivers of reforms in the AIS index: principal component analysis

\begin{tabular}{|c|c|c|c|c|c|c|}
\hline & (1) & (2) & (3) & (4) & (5) & (6) \\
\hline AIS Index (2007) & $\begin{array}{c}-0.7264 * * * \\
(0.239)\end{array}$ & $\begin{array}{c}-0.9958 * * * \\
(0.264)\end{array}$ & $\begin{array}{c}-0.7246^{* * *} \\
(0.238)\end{array}$ & $\begin{array}{c}-0.9930 * * * \\
(0.264)\end{array}$ & $\begin{array}{c}-0.7597 * * * \\
(0.234)\end{array}$ & $\begin{array}{c}-1.1575 * * * \\
(0.248)\end{array}$ \\
\hline$\Delta$ Central Bank as Supervisor & $\begin{array}{l}0.9639 * * * \\
(0.219)\end{array}$ & & $\begin{array}{l}0.9554 * * * \\
(0.224)\end{array}$ & & $\begin{array}{c}1.2838 * * * \\
(0.306)\end{array}$ & \\
\hline $\begin{array}{l}\Delta \text { Central Bank as Financial } \\
\text { Sector Supervisor }\end{array}$ & & $\begin{array}{c}0.3351 * * * \\
(0.076)\end{array}$ & & $\begin{array}{c}0.3339 * * * \\
(0.074)\end{array}$ & & $\begin{array}{c}0.3808 * * * \\
(0.103)\end{array}$ \\
\hline Financial Crisis & $\begin{array}{c}-1.0634 * * \\
(0.536)\end{array}$ & $\begin{array}{r}-1.0532 \\
(0.688)\end{array}$ & $\begin{array}{c}-1.0958 * * \\
(0.539)\end{array}$ & $\begin{array}{l}-1.1215 \\
(0.683)\end{array}$ & $\begin{array}{l}-0.7375 \\
(0.532)\end{array}$ & $\begin{array}{l}-0.1789 \\
(0.627)\end{array}$ \\
\hline Private credit to GDP & $\begin{array}{l}0.0036 \\
(0.003)\end{array}$ & $\begin{array}{l}0.0028 \\
(0.003)\end{array}$ & $\begin{array}{l}0.0040 \\
(0.003)\end{array}$ & $\begin{array}{l}0.0033 \\
(0.003)\end{array}$ & $\begin{array}{l}0.0023 \\
(0.003)\end{array}$ & $\begin{array}{l}0.0009 \\
(0.004)\end{array}$ \\
\hline GDP per capita & $\begin{array}{l}0.0001 \\
(0.000)\end{array}$ & $\begin{array}{l}0.0001 \\
(0.000)\end{array}$ & $\begin{array}{l}0.0001 \\
(0.000)\end{array}$ & $\begin{array}{l}0.0001 \\
(0.000)\end{array}$ & $\begin{array}{l}0.0001 \\
(0.000)\end{array}$ & $\begin{array}{l}-0.0001 \\
(0.000)\end{array}$ \\
\hline$\Delta$ Supervisory practices & $\begin{array}{l}0.2641^{*} \\
(0.150)\end{array}$ & $\begin{array}{c}0.3856^{* *} \\
(0.186)\end{array}$ & $\begin{array}{l}0.2704 * \\
(0.151)\end{array}$ & $\begin{array}{c}0.3994 * * \\
(0.180)\end{array}$ & $\begin{array}{l}0.2905 \\
(0.193)\end{array}$ & $\begin{array}{l}0.3957 * \\
(0.238)\end{array}$ \\
\hline Regulatory Quality & & & $\begin{array}{l}-0.0627 \\
(0.240)\end{array}$ & $\begin{array}{l}-0.1034 \\
(0.271)\end{array}$ & $\begin{array}{l}-0.1791 \\
(0.311)\end{array}$ & $\begin{array}{c}-0.0444 \\
(0.336)\end{array}$ \\
\hline Actions Vs Banks & & & & & $\begin{array}{l}-0.0006 \\
(0.002)\end{array}$ & $\begin{array}{c}-0.0012 \\
(0.002)\end{array}$ \\
\hline Actions Vs Auditors & & & & & $\begin{array}{c}0.0294^{* *} \\
(0.012)\end{array}$ & $\begin{array}{l}0.0245^{*} \\
(0.013)\end{array}$ \\
\hline Big4 & & & & & $\begin{array}{l}0.0814 \\
(0.067)\end{array}$ & $\begin{array}{l}0.0483 \\
(0.083)\end{array}$ \\
\hline Common Law Legal Origin & & & & & $\begin{array}{l}0.5624 \\
(0.358)\end{array}$ & $\begin{array}{l}0.3132 \\
(0.417)\end{array}$ \\
\hline Public Credit Registry & & & & & $\begin{array}{l}0.1336 \\
(0.342)\end{array}$ & $\begin{array}{l}-0.1691 \\
(0.425)\end{array}$ \\
\hline Pseudo R-squared & 0.10 & 0.12 & 0.10 & 0.12 & 0.14 & 0.14 \\
\hline Observations & 76 & 51 & 76 & 51 & 72 & 48 \\
\hline
\end{tabular}

The dependent variable is the modified $\triangle$ AIS Index, i.e. the change in the AIS Index computed using the weights obtained from the principal component analysis between 2007 and 2012. AIS Index (2007) is the modified degree of external auditors' involvement in supervision in 2007. $\Delta$ Central Bank as Supervisor/ Central Bank as Financial Sector Supervisor captures the change in the degree of central bank involvement in banking sector and financial sector supervision, respectively between 2007 and 2012. Financial crisis is a dummy that takes the value one for countries experiencing a systemic banking crisis between 2007 and 2012. $\Delta$ Supervisory Practices captures the changes in supervisory practices adopted by a country in 2012 as compared to 2007. Regulatory Quality captures perceptions of the ability of the government to formulate and implement sound policies and regulations that permit and promote private sector development. Actions vs Banks/Auditors provides information on the number of actions that have been taken by the supervisor in the period 2006-2010 against banks/auditors. Big4 is a measure of the number of the ten biggest banks supervised by the big four auditing companies in the country. Common Law Legal Origin is a variable for common law countries. Public Credit Registry is a dummy for the presence of public credit registries in 2011. Robust standard errors in parentheses. $* * *$ denotes significance at a $1 \%$ level, $* *$ denotes significance at a $5 \%$ level, $*$ denotes significance at a $10 \%$ level.

\subsection{The role of central bank independence}

One of the main determinants of reforms in auditors' involvement in supervision was found to be the increased role of the central bank in financial sector supervision. At the same time, the presence of a financial crisis played a lesser role. One might argue, however, that the changes in central bank involvement in supervision follow episodes of financial distress, which are often seen as a supervisory failure (see Masciandaro and Romelli, 2018). To test this hypothesis, Table 4 replicates our main estimates by adding an interaction term between the measure of changes in the degree of central bank involvement in supervision and the crisis 
dummy. This interaction captures the effect of an increasing role of central banks in supervision, in countries that have experienced a financial crisis.

The model including these interactive terms is presented in Table 4. Columns (1)-(2) employ the equally weighted AIS index, while columns (3)-(4) the AIS index using PCA weights. Across these estimations, the interaction term between the change in central bank involvement in supervision and the crisis dummy is statistically significant at the $5 \%$ level. The positive sign of these coefficients suggests that, among crisis countries, those that have placed more supervisory powers in the hand of the central bank are also more likely to have increased their involvement of auditors in supervision.

These results confirm the importance of the degree of central bank involvement in supervision, i.e. situations in which the benefits of increasing auditors' involvement in supervision are higher, given the various tasks in which monetary policy institutions might be involved. At the same time, a longstanding literature has focused on the concept of credibility of central banks and the costs associated to the loss of such credibility. This issue is even more relevant in contexts in which the central bank is more independent. As such, the reputational costs in terms of lost credibility ought to be higher among the most independent central banks that are also involved in financial sector supervision. We thus expect these supervisors to be more likely to involve external auditors in supervision.

In order to capture this mechanism, Columns (5)-(8) in Table 4 look at the probability of implementing a reform in the AIS index among countries that have highly independent central banks whose role as a supervisor has increased. This effect is captured by an interaction term between the changes in the degree of central bank involvement in banking and financial sector supervision and the degree of central bank independence (CBI). We obtain a dynamic index of CBI from Romelli (2018). The positive and statistically significant coefficients of these interaction terms suggest that changes in the AIS Index are higher in countries that have increased the involvement of their central bank in supervision, in contexts in which the central bank is more independent. 
Table 4: Reforms in auditors' involvement in supervision: robustness checks

\begin{tabular}{|c|c|c|c|c|c|c|c|c|}
\hline \multirow[t]{2}{*}{ Dependent variable: } & \multicolumn{2}{|c|}{$\Delta$ AIS Index } & \multicolumn{2}{|c|}{$\Delta$ AIS Index (PCA) } & \multicolumn{2}{|c|}{$\Delta$ AIS Index } & \multicolumn{2}{|c|}{$\Delta$ AIS Index (PCA) } \\
\hline & (1) & (2) & (3) & (4) & (5) & (6) & $(7)$ & (8) \\
\hline AIS Index (2007) & $\begin{array}{l}-0.8841^{* * *} \\
(0.233)\end{array}$ & $\begin{array}{c}-1.2696 * * * \\
(0.280)\end{array}$ & $\begin{array}{c}-0.7497 * * * \\
(0.239)\end{array}$ & $\begin{array}{c}-1.1512 * * * \\
\quad(0.229)\end{array}$ & $\begin{array}{l}-1.2276^{* * *} \\
(0.272)\end{array}$ & $\begin{array}{c}-1.1759^{* * *} \\
(0.282)\end{array}$ & $\begin{array}{c}-1.1129 * * * \\
(0.219)\end{array}$ & $\begin{array}{c}- \\
1.0602 * * * \\
(0.237)\end{array}$ \\
\hline $\begin{array}{l}\Delta \mathrm{CB} \text { as Supervisor } \mathrm{x} \\
\text { Crisis }\end{array}$ & $\begin{array}{c}1.0781 * * \\
(0.454)\end{array}$ & & $\begin{array}{c}1.0843 * * \\
(0.432)\end{array}$ & & & & & \\
\hline $\begin{array}{l}\Delta \mathrm{CB} \text { as Financial Sector } \\
\text { Supervisor } \mathrm{x} \text { Crisis }\end{array}$ & & $\begin{array}{c}0.3845^{* *} \\
(0.187)\end{array}$ & & $\begin{array}{c}0.3314 * * \\
(0.148)\end{array}$ & & & & \\
\hline $\begin{array}{l}\triangle \mathrm{CB} \text { as Supervisor } \\
\text { Index } \mathrm{x} C \mathrm{CBI}\end{array}$ & & & & & $\begin{array}{c}2.0838 * * * \\
(0.569)\end{array}$ & & $\begin{array}{l}1.4091 * * * \\
(0.430)\end{array}$ & \\
\hline $\begin{array}{l}\Delta \mathrm{CB} \text { as Financial Sector } \\
\text { Supervisor } \mathrm{x} C \mathrm{CBI}\end{array}$ & & & & & & $\begin{array}{c}0.5502 * * \\
(0.217)\end{array}$ & & $\begin{array}{c}0.4384 * * * \\
(0.136)\end{array}$ \\
\hline Financial Crisis & $\begin{array}{c}-0.7616 \\
(0.576)\end{array}$ & $\begin{array}{l}0.7307 \\
(0.770)\end{array}$ & $\begin{array}{l}-0.7258 \\
(0.539)\end{array}$ & $\begin{array}{l}0.7391 \\
(0.755)\end{array}$ & $\begin{array}{l}-0.9382 \\
(0.746)\end{array}$ & $\begin{array}{r}-0.3840 \\
(0.678)\end{array}$ & $\begin{array}{l}-0.8227 \\
(0.684)\end{array}$ & $\begin{array}{r}-0.3874 \\
(0.671)\end{array}$ \\
\hline
\end{tabular}

Additional controls: Private credit to GDP; GDP per capita; 4 Supervisory practices; Regulatory Quality; Actions vs Banks; Actions vs Auditors; Big4; Common Law Legal Origin; Public Credit Registry

\begin{tabular}{lcccccccc}
\hline Pseudo R-squared & 0.24 & 0.28 & 0.11 & 0.14 & 0.34 & 0.30 & 0.16 & 0.15 \\
Observations & 72 & 45 & 72 & 45 & 61 & 45 & 61 & 45 \\
\hline \hline
\end{tabular}

The dependent variable is $\triangle$ AIS Index, i.e. the change in the AIS Index between 2007 and 2012, where the AIS index is computed using equal weights in columns (1)-(4) and the Principal Component Analysis (PCA) weights in columns (5)-(8). AIS Index (2007) is the degree of external auditors' involvement in supervision in 2007. $\Delta$ Central Bank as Supervisor Index/ Central Bank as Financial Sector Supervisor Index captures the change in the degree of central bank involvement in banking sector and financial sector supervision, respectively between 2007 and 2012. Financial crisis is a dummy that takes the value one for countries experiencing a systemic banking crisis between 2007 and 2012. $\Delta$ CB as Supervisor Index/ Central Bank as Financial Sector Supervisor Index * Crisis is the interaction term between the change in the degree of central bank involvement in banking and financial sector supervision between 2007 and 2012 and the Financial Crisis dummy. $\triangle \mathrm{CB}$ as Supervisor Index/ Central Bank as Financial Sector Supervisor Index * CBI is the interaction term between the change in the degree of central bank involvement in banking sector and financial sector supervision, respectively between 2007 and 2012 and the degree of independence of the country's central bank. $\Delta$ Supervisory Practices captures the changes in supervisory practices adopted by a country in 2012 as compared to 2007. Regulatory Quality captures perceptions of the ability of the government to formulate and implement sound policies and regulations that permit and promote private sector development. Actions vs Banks/Auditors provides information on the number of actions that have been taken by the supervisor in the period 2006-2010 against banks/auditors. Big4 is a measure of the number of the ten biggest banks supervised by the big four auditing companies in the country. Common Law Legal Origin is a dummy for common law countries. Public Credit Registry is a dummy for the presence of public credit registries in 2011 . Robust standard errors in parentheses. ${ }^{* * *}$ denotes significance at a $1 \%$ level, ${ }^{* *}$ denotes significance at a $5 \%$ level, $*$ denotes significance at a $10 \%$ level.

\subsection{Robustness checks and causality}

We test the sensitivity of our results to alternative empirical strategies. A related methodological approach is to look at the determinants of the level of the AIS Index, as opposed to the change in the index. Assuming that the same set of factors can explain the level of auditors' involvement in banking supervision, we now estimate the following model:

$$
\begin{aligned}
\text { AIS }_{i, 2012}=\alpha & +\beta_{1} \text { AIS }_{i, 2007}+\beta_{2} \text { Central Bank in Supervision }_{i, 2011}+\beta_{3} \text { Crisis }_{i}+\beta_{4}{ }^{\prime} X \\
& +\epsilon_{i}
\end{aligned}
$$

where $A I S_{i, 2012}$ is the level of the index 2012;AIS $S_{i, 2007}$ is the index in 2007; Central Bank in Supervision ${ }_{i, 2011}$ captures the degree of central bank involvement in financial sector supervision in 2011; Crisis $_{i}$ is a dummy that takes the value one for countries 
experiencing a systemic banking crisis as defined in Laeven and Valencia (2013) over the period 2007-2012; while $X$ is the same vector of country characteristics employed in the previous section.

Looking at the level as opposed to the changes in the index will also allow us to investigate the role of these covariates on the different components of the AIS Index, not just its overall level. As such, Columns (1), (2) and (3) in Table 5 show the OLS estimations for each of the three sub-indices related to auditor and auditing requirements, as well as, auditor-supervisor relationship. Columns (4) and (5) look at the aggregated AIS Index computed using equal weights and principal component weights, respectively. Overall, the results obtained are qualitatively similar to the ordered probit estimations, both for the overall level as well as the sub-components. In addition, we find that GDP per capita is robustly linked to the level of the indices, suggesting that more developed economies have, on average, a higher involvement of external auditors in banking supervision. 
Table 5: The level of the AIS index: OLS estimates

\begin{tabular}{|c|c|c|c|c|c|}
\hline & (1) & (2) & (3) & (4) & $(5)$ \\
\hline Auditor Requirements (2007) & $\begin{array}{l}0.3203 \\
(0.380)\end{array}$ & & & & \\
\hline Auditing Requirements (2007) & & $\begin{array}{c}0.2402 * * \\
(0.100)\end{array}$ & & & \\
\hline Auditor/supervisor relationship (2007) & & & $\begin{array}{l}0.2425 \\
(0.189)\end{array}$ & & \\
\hline AIS Index (2007) & & & & $\begin{array}{l}0.1156 \\
(0.175)\end{array}$ & \\
\hline AIS Index (2007, PCA) & & & & & $\begin{array}{l}0.1352 \\
(0.191)\end{array}$ \\
\hline $\begin{array}{l}\text { Central Bank as Financial Sector } \\
\text { Supervisor Index }\end{array}$ & $\begin{array}{l}0.1436 * * \\
(0.065)\end{array}$ & $\begin{array}{l}0.1259 * * \\
(0.050)\end{array}$ & $\begin{array}{l}-0.0093 \\
(0.058)\end{array}$ & $\begin{array}{l}0.2463 * * \\
(0.107)\end{array}$ & $\begin{array}{l}0.0765 * * \\
(0.032)\end{array}$ \\
\hline Financial Crisis & $\begin{array}{l}-0.5392 \\
(0.396)\end{array}$ & $\begin{array}{l}-0.1158 \\
(0.305)\end{array}$ & $\begin{array}{l}-0.6492 * \\
(0.359)\end{array}$ & $\begin{array}{c}-1.4166^{* *} \\
(0.639)\end{array}$ & $\begin{array}{c}-0.5006^{* *} \\
(0.217)\end{array}$ \\
\hline Private credit to GDP & $\begin{array}{l}-0.0031 \\
(0.002)\end{array}$ & $\begin{array}{l}-0.0009 \\
(0.003)\end{array}$ & $\begin{array}{l}0.0018 \\
(0.003)\end{array}$ & $\begin{array}{l}-0.0006 \\
(0.006)\end{array}$ & $\begin{array}{l}0.0001 \\
(0.002)\end{array}$ \\
\hline GDP per capita & $\begin{array}{c}0.0001^{* *} \\
(0.000)\end{array}$ & $\begin{array}{l}-0.0001 \\
(0.000)\end{array}$ & $\begin{array}{c}0.0001^{* *} \\
(0.000)\end{array}$ & $\begin{array}{l}0.0001^{* * *} \\
(0.000)\end{array}$ & $\begin{array}{c}0.0001 * * \\
(0.000)\end{array}$ \\
\hline Supervisory practices & $\begin{array}{l}0.2171^{*} \\
(0.128)\end{array}$ & $\begin{array}{c}0.3414^{* *} \\
(0.148)\end{array}$ & $\begin{array}{l}0.1397 \\
(0.157)\end{array}$ & $\begin{array}{l}0.7263^{* * * *} \\
(0.252)\end{array}$ & $\begin{array}{c}0.2338^{* * * *} \\
(0.082)\end{array}$ \\
\hline Regulatory Quality & $\begin{array}{c}-0.0518 \\
(0.154)\end{array}$ & $\begin{array}{l}0.2652 \\
(0.181)\end{array}$ & $\begin{array}{c}-0.4434^{* *} \\
(0.179)\end{array}$ & $\begin{array}{l}-0.3079 \\
(0.351)\end{array}$ & $\begin{array}{l}-0.0929 \\
(0.110)\end{array}$ \\
\hline Common Law Legal Origin & $\begin{array}{c}-0.0772 \\
(0.128)\end{array}$ & $\begin{array}{l}0.1654 \\
(0.188)\end{array}$ & $\begin{array}{c}-0.2486 \\
(0.204)\end{array}$ & $\begin{array}{c}-0.1674 \\
(0.306)\end{array}$ & $\begin{array}{c}-0.0676 \\
(0.090)\end{array}$ \\
\hline Public Credit Registry & $\begin{array}{l}0.1020 \\
(0.211)\end{array}$ & $\begin{array}{l}-0.0195 \\
(0.195)\end{array}$ & $\begin{array}{l}0.0876 \\
(0.193)\end{array}$ & $\begin{array}{l}0.1849 \\
(0.337)\end{array}$ & $\begin{array}{l}0.0524 \\
(0.105)\end{array}$ \\
\hline R-squared & 0.300 & 0.305 & 0.190 & 0.265 & 0.290 \\
\hline Observations & 56 & 56 & 56 & 56 & 56 \\
\hline \multicolumn{6}{|c|}{$\begin{array}{l}\text { The dependent variable in column (1) is the } 2012 \text { level of the sub-component of the AIS Index related to auditor requirements, in column (2) } \\
\text { related to auditing requirements, while in column (3) to auditor-supervisor relationship. The dependent variable in columns (4)-(5) is the AIS } \\
\text { index in } 2012 \text {, computed using equal weights in column (4) and the Principal Component Analysis weights in column (5). AIS Index (2007) } \\
\text { is the degree of external auditors' involvement in supervision in } 2007 \text {. Central Bank as Supervisor Index/ Central Bank as Financial Sector } \\
\text { Supervisor Index captures the degree of central bank involvement in banking and financial sector supervision in 2011. Financial crisis is a } \\
\text { dummy that takes the value one for countries experiencing a systemic banking crisis between } 2007 \text { and } 2012 \text {. Supervisory Practices captures } \\
\text { the supervisory practices in a country in } 2011 \text {. Regulatory Quality captures perceptions of the ability of the government to formulate and } \\
\text { implement sound policies and regulations that permit and promote private sector development in } 2011 \text {. Common Law Legal Origin is a } \\
\text { variable for common law countries. Public Credit Registry is a dummy for the presence of public credit registries in } 2011 \text {. A constant term is } \\
\text { included but not reported. Robust standard errors in parentheses. *** denotes significance at a } 1 \% \text { level, ** denotes significance at a } 5 \% \text { level, }\end{array}$} \\
\hline
\end{tabular}

Our results show a robust link between various institutional settings and both the level as well as change in the AIS index. In this initial exploration of the link between auditor involvement in supervision and institutional factors, we have not addressed issues of causality and simply discuss some robust correlations. However, it is important to note that some of the results are subject to endogeneity and omitted variables biases. Specifically, the close link between changes in central bank involvement in supervision and changes in auditor involvement can be subject to reverse causality concerns or be driven by the same omitted factors. Given the limited time span of our data, addressing issues of causality can be cumbersome. Nonetheless, we provide several tests where we attempt to mitigate these 
concerns. ${ }^{16}$ First, we test the robustness of the results presented in Table 5 by running generalized method of moments (GMM) estimations. Specifically, we aim to instrument the level of the indices of involvement of central banks in supervision using their lagged values to control for reverse causality concerns. To do so, we first need to extend the time series dimension of our data. As the full set of variables employed in constructing the AIS index collected from the World Bank Survey are only available for 2007 and 2012, we create a restricted version of the AIS Index, based on the set of information available in the three most recent vintages of the World Bank's Bank Regulation and Supervision Survey, i.e. 2003, 2007 and 2012. ${ }^{17}$ The results of these estimations are presented in Appendix Table D.2, where the AIS Index, Central Bank as Supervisor and Central Bank as Financial Supervisor are instrumented by their lagged values. The Hansen (1982) test of overidentifying restrictions suggests that this set of instruments is valid. The instrumented indices of central bank involvement in supervision are still robustly related to the level of the AIS Index, suggesting they are important drivers of reforms in the degree of external auditors' involvement in banking supervision.

Second, we perform a series of Placebo tests by randomizing the indices of central bank involvement in banking and financial sector supervision across the sample of countries in Appendix Table D.3. The lack of significance of the randomized change in these indices confirms that the link between changes in the degree of auditors' involvement and the variations in central bank involvement in supervision is robust and not an artifact of the data.

\section{CONCLUSION}

This paper studies the determinants of external auditors' involvement in banking sector supervision from a theoretical and empirical perspective. First, in a simple principal-agent framework, we highlight the importance of several country-specific institutional characteristics in determining the optimal involvement of external auditors in supervision. The model suggests that one size does not fit all: each national policymaker must form expectations regarding the potential benefits and costs from external auditor involvement in banking supervision, which depend on, among others, the quality of auditing reports and the risk of capture of auditors by the financial sector.

Therefore, rather than pursuing a normative analysis, in the empirical part of the paper, we take a positive approach and propose a new index that captures the actual level of external auditor involvement in banking supervision in a broad set of countries. To this aim, we collect information from the 2007 and 2012 Bank Regulation and Supervision Surveys of the World Bank for a sample of 115 countries and build a new index called Auditors' Involvement in Supervision (AIS Index). In constructing this index, we consider three sets of qualitative characteristics of supervisory regimes: auditor requirements, auditing requirements and the auditor/supervisor relationship. We employ this institutional indicator to analyze, in a

\footnotetext{
${ }^{16}$ We thank an anonymous referee for this suggestion.

${ }^{17}$ This restricted index only contains information related to 7 of the 9 questions in Table 1. A full description of this restricted index is available upon request.
} 
systematic way, the state of auditors' involvement in supervision. We find that the average level of the AIS Index in 2012 is equal to 8 out of a maximum of 9, suggesting a high level of auditors' involvement in banking supervision across the world.

Guided by the theoretical model, we then provide a set of proxies of the most important institutional characteristics that can explain the likelihood of reforming the degree of auditors' involvement in banking supervision. We find that countries that have increased the role of their central banks in supervision from 2007 to 2012 are also more likely to involve auditors in supervision, suggesting that the added complexity of a supervisory function is likely to benefit from the expertise of an external auditor. We proxy the costs of involving an auditor by the reputational failure of supervisors that have experienced a systemic banking crisis over the period considered. We show that, among countries that have increased the role of their central bank as supervisor, those experiencing a financial crisis are also more likely to involve auditors in supervision. Finally, we find that countries characterized by lower levels of the AIS Index have the highest probability of reforming the involvement of external auditors in supervision, suggesting that the reform process is path-dependent. The likelihood of reforms is also affected by other changes in the supervisory practices taking place in a country, as well as by the quality of auditing and/or regulation of a country.

These results bring new insights into the institutional determinants of supervisory frameworks across countries and can help understand the main drivers behind the reforms undertaken by countries since the Global financial crisis. 


\section{REFERENCES}

Abascal, R. and Gonzales, F., 2019, Shareholder Protection and Bank Executive Compensation after the Global Financial Crisis, Journal of Financial Stability, vol. 40, 15-37.

Abiad, A., and Mody, A., 2005. Financial reform: what shakes it? What shapes it? American Economic Review 95 (1), 66-88.

Alesina, A. and Tabellini G., 2007, Bureaucrats or Politicians? Part I: A Single Policy Task, American Economic Review, 97, 169-179.

Alvis, K., 2015, Accounting Credibility and Liquidity Constraints: Evidence from Reactions of Small Banks to Monetary Tightening, Accounting Review, 90(3), 1079-1113.

Anginer, D., Demirguc-Kunt, A. and Mare, D.E., 2018, Bank Capital, Institutional Environment and Systemic Stability, Journal of Financial Stability, vol. 37, 97-106.

Aparicio, J., Duran, M. A., Lozano-Vivas, A. and Pastor, J.T., 2018, Are Charter Value and Supervision Aligned? A Segmentation Analysis, Journal of Financial Stability, vol. 37, 60-73.

Barth, J., Caprio, G. and Levine, R., 2004. Bank regulation and supervision: what works best? Journal of Financial Intermediation 13 (2), 205-248.

Barth, J., Caprio, G. and Levine R., 2013, Bank Regulation and Supervision in 180 Countries from 1999 to 2011, NBER Working Paper Series, National Bureau of Economic Research, n.18733.

Basel Committee on Banking Supervision, 2008, External Audit Quality and Banking Supervision, Bank for International Settlements, December.

Basel Committee on Banking Supervision, 2014, External Audits of banks, Bank for International Settlements, March.

Belhaj, M. and Klimenko, N., 2013, Optimal Preventive Bank Supervision Combining Random Audits and Continuous Intervention, AMSE Working Papers 1201, Aix-Marseille School of Economics, Marseille, France.

Blankespoor, E., Linsmeier, T.J., Petroni, K.R. and Shakespeare, K., 2013, Fair Value Accounting for Financial Instruments: Does It Improve the Association between Banking Leverage and Credit Risk?, Accounting Review, 88(4), 1143-1177.

Cabrera, M., Dwyer, G.P. and Nieto, M.J., 2018, The G-20's Regulatory Agenda and Banks' Risk, Journal of Financial Stability, vol. 39, 66-78.

Cihak, M., Demirgüç-Kunt, A., Peria, M.S.M. and Mohseni-Cheraghlou, A., 2013. Bank regulation and supervision in the context of the global crisis. Journal of Financial Stability, 9(4), pp.733-746.

Dalla Pellegrina, L. and Masciandaro, D., 2009, The Risk Based Approach in the New European Anti-Money Laundering Legislation: a Law and Economics View, Review of Law and Economics, 5(2), 290-317.

De Chiara, A., Livio, L. and Ponce, J., 2018, Flexible and Mandatory Banking Supervision, Journal of Financial Stability, vol. 34, 86-104.

Dewing, I.P. and Russell, P.O., 2010, The Contrasting Role of Auditors in UK and Swiss Banking Supervision, The Institute of Chartered Accountants of Scotland, Edinburgh. 34 (6-7), 810-825. 
Djankov, S., McLiesh, C. and Shleifer, A., 2007, Private credit in 129 countries. Journal of Financial Economics, 84(2), pp.299-329.

Giuliano, P., Mishra, P. and Spilimbergo, A., 2013, Democracy and reforms: evidence from a new dataset, American Economic Journal: Macroeconomics, 5 (4), 179-204.

Gokmen, G., Nannicini, T., Onorato, M. G. and Papageorgiou, C., 2017, Policies in hard times: assessing the impact of financial crises on structural reforms, IGIER Working Paper 605.

Hwa, V., Kapinos P., and Ramirez, C.D., 2018, Does regulatory bank oversight impact economic activity? A local projections approach?, Journal of Financial Stability, vol. 39, 167-174.

Humphrey, C., Loft, A. and Woods, M., 2009, The Global Audit Profession and the International Financial Architecture: Understanding Regulatory Relationships at a Time of Financial Crisis, Accounting, Organizations and Society.

Kaufmann, D., Kraay, A. and Mastruzzi, M., 2010. The worldwide governance indicators: methodology and analytical issues. Policy Research Working Paper Series 5430, The World Bank.

Kofman, F. and Lawarrée, J., 1993, Collusion in Hierarchical Agency, Econometrica, 61(3), 629-659.

Kupiec, P., Lee, Y. and Rosenfeld, C., 2017, Does Bank Supervision Impact Bank Loan Growth? Journal of Financial Stability, vol. 28, 29-48.

Laeven, L., and Valencia, F., 2012. Systemic Banking Crisis Database: An Update. IMF Working Paper 08/224.

Masciandaro, D., Nieto M.J. and Quintyn, M., 2011, Exploring Governance of the New European Banking Authority: A Case for Harmonization?, Journal of Financial Stability, vol. 7, n.4, 204-214.

Masciandaro, D. and Quintyn, M., 2013, The Evolution of Financial Supervision: the Continuing Search for the Holy Grant, in M. Balling and E. Gnan (eds), 50 Years of Money and Finance, Larcier, Paris, 263-318.

Masciandaro, D., Pansini R.V. and Quintyn, M., 2013, The Economic Crisis: Did Supervisory Architecture and Governance Matter?, Journal of Financial Stability, vol. 9, n.4, 578596.

Masciandaro, D. and Romelli, D., 2018. Central Bankers as Supervisors: Do Crises Matter? European Journal of Political Economy, vol. 52 (March), 120-140.

Merrouche, O., and Nier, E., 2010. What Caused the Global Financial Crisis; Evidence on the Drivers of Financial Imbalances 1999: 2007. IMF Working Paper 10/265.

Ojo, M., 2012a, A Global Perspective on the Changing Perceptions of the Role of the External Auditor and the Significance of Audit Developments, MPRA Working Paper Series Munich, n. 36471.

Ojo, M., 2012b, Why the Transfer of Bank Supervisory Powers back to the Bank of England is a Step in the Right Direction: Revisiting the Role of External Auditors in Bank and Financial Services Supervision, MPRA Working Paper Series Munich, n. 43387.

Ojo, M., 2014, A Justification for the Role of Audits? Adoption of IFRS and Jurisdictional Analyses (Brazil, China, Japan and South Africa), MPRA Working Paper Series Munich, n. 57826. 
Romelli, D., 2018. The political economy of reforms in central bank design: evidence from a new dataset. Trinity Economic Papers, tep0918.

Singh, D., 2013, The Role of External Auditors in Bank Supervision: A Supervisory Gatekeeper? The International Lawyer, 47(1), 101-166.

Stigler, G., 1971, The Theory of Economic Regulation, Bell Journal of Economics and Management Science, 2, 3-21.

Stigler, G., 1975, The Citizen and the State: Essays on Regulation, University of Chicago Press, Chicago.

Valencia, O.C. and Bolanos, A.O., 2018, Bank Capital Buffers around the World: Cyclical Patterns and the Effect of Market Power, Journal of Financial Stability, vol. 38, 119131. 


\section{APPENDIX A}

The solution to the optimization problem in Section 2.3 is presented below.

The optimal supervisory framework in Eq. (9) has the Lagrangian:

$\mathcal{L}=p\left\{Q_{1}+e_{1}-J_{1}+\gamma\left[(1-r) P_{B}-Z\right]\right\}+(1-p)\left\{Q_{2}+e_{2}-J_{2}\right\}+\lambda_{1}\left\{J_{1}-\frac{e_{1}^{2}}{2}-\right.$
$\left.\gamma(1-r) P_{B}\right\}+\lambda_{2}\left\{J_{2}-\frac{e_{2}^{2}}{2}\right\}+\lambda_{3}\left\{J_{2}-\frac{e_{2}^{2}}{2}-J_{1}+\frac{\left(e_{1}-\Delta Q\right)^{2}}{2}+\gamma r P_{B}\right\}+\lambda_{4}\{1-\gamma\}$

We are interested in positive solutions, i.e., $e_{1}>0, e_{2}>0, t_{1}>0, t_{2}>0$. As such the remaining Kuhn-Tucker conditions for the maximization problem above are:

(1) $\frac{\partial \mathcal{L}}{\partial e_{1}}=p-\lambda_{1} e_{1}+\lambda_{3}\left(e_{1}-\Delta Q\right)=0$

(2) $\frac{\partial \mathcal{L}}{\partial e_{2}}=(1-p)-\left(\lambda_{2}+\lambda_{3}\right) e_{2}=0$

(3) $\frac{\partial \mathcal{L}}{\partial J_{1}}=-p+\lambda_{1}-\lambda_{3}=0 \Rightarrow \lambda_{1}-\lambda_{3}=p$

(4) $\frac{\partial \mathcal{L}}{\partial J_{2}}=-(1-p)+\lambda_{2}+\lambda_{3}=0 \Rightarrow \lambda_{2}+\lambda_{3}=(1-p)$

(5) $\frac{\partial \mathcal{L}}{\partial \gamma}=p(1-r) P_{B}-p Z-\lambda_{1}(1-r) P_{B}+\lambda_{3} r P_{B}-\lambda_{4} \leq 0 ; \gamma \frac{\partial L}{\partial \gamma}=0$.

From (2) and (3) it follows that $e_{2}=1$, while from (1) and (3): $e_{1}=1-\frac{\lambda_{3}}{p} \Delta Q$. Substituting $\lambda_{1}=\lambda_{3}+p$ from (3) in (5), we obtain:

$$
P_{B}(2 r-1) \lambda_{3}-\lambda_{4}-p Z \leq 0 .
$$

From (4) it follows that $\lambda_{3} \leq(1-p)$, so $\gamma>0$, only if

$$
P_{B}(2 r-1)(1-p)-\lambda_{4}-p Z \geq 0,
$$

or

$$
P_{B} \geq \frac{p Z}{(2 r-1)(1-p)}
$$




\section{APPENDIX B}

Table B.1: The AIS Index (2007-2012)

\begin{tabular}{|c|c|c|c|c|c|c|c|c|c|c|c|c|c|c|c|c|c|c|c|c|}
\hline \multirow[b]{2}{*}{ Country } & \multicolumn{2}{|c|}{ AuditorReq1 } & \multicolumn{2}{|c|}{ AuditorReq2 } & \multicolumn{2}{|c|}{ AuditorReq3 } & \multicolumn{2}{|c|}{ AuditingReq1 } & \multicolumn{2}{|c|}{ AuditingReq2 } & \multicolumn{2}{|c|}{ AuditingReq3 } & \multicolumn{2}{|c|}{ AuditingReq4 } & \multicolumn{2}{|c|}{ AudSupRel1 } & \multicolumn{2}{|c|}{ AudSupRel2 } & \multicolumn{2}{|c|}{ AIS Index } \\
\hline & 2007 & 2012 & 2007 & 2012 & 2007 & 2012 & 2007 & 2012 & 2007 & 2012 & 2007 & 2012 & 2007 & 2012 & 2007 & 2012 & 2007 & 2012 & 2007 & 2012 \\
\hline Angola & 1 & 1 & 0 & 1 & 1 & 1 & 1 & 1 & 1 & 1 & 1 & 1 & 1 & 1 & 0 & 1 & 1 & 1 & 7 & 9 \\
\hline Argentina & 1 & 1 & 1 & 1 & 1 & 1 & 1 & 0 & 1 & 1 & 1 & 1 & 0 & 0 & 1 & 1 & 1 & 1 & 8 & 7 \\
\hline Armenia & 1 & 1 & 1 & 1 & 1 & 1 & 1 & 1 & 1 & 1 & 1 & 1 & 1 & 1 & 1 & 1 & 1 & 0 & 9 & 8 \\
\hline Australia & 1 & 1 & 1 & 1 & 1 & 1 & 1 & 1 & 1 & 1 & 1 & 1 & 0 & 1 & 1 & 1 & 1 & 1 & 8 & 9 \\
\hline Austria & 1 & 1 & 1 & 1 & 1 & 1 & 1 & 0 & 0 & 1 & 1 & 1 & 1 & 0 & 1 & 1 & 1 & 1 & 8 & 7 \\
\hline Bahrain & 1 & 1 & 1 & 1 & 1 & 1 & 1 & 1 & 1 & 1 & 1 & 1 & 1 & 1 & 1 & 1 & 1 & 1 & 9 & 9 \\
\hline Bangladesh & 1 & 1 & 1 & 1 & 1 & 1 & 1 & 1 & 1 & 1 & 1 & 1 & 1 & 0 & 1 & 1 & 1 & 1 & 9 & 8 \\
\hline Belarus & 1 & 1 & 1 & 1 & 1 & 1 & 1 & 0 & 1 & 1 & 1 & 1 & 0 & 1 & 1 & 1 & 0 & 1 & 7 & 8 \\
\hline Belgium & 1 & 1 & 1 & 1 & 1 & 1 & 1 & 1 & 1 & 1 & 1 & 1 & 1 & 1 & 1 & 1 & 1 & 1 & 9 & 9 \\
\hline Belize & 1 & 1 & 1 & 1 & 1 & 1 & 1 & 1 & 1 & 1 & 1 & 1 & 1 & 1 & 1 & 1 & 1 & 1 & 9 & 9 \\
\hline Benin & 1 & 1 & 1 & 1 & 1 & 1 & 1 & 1 & 0 & 1 & 1 & 1 & 1 & 1 & 1 & 1 & 1 & 1 & 8 & 9 \\
\hline Bhutan & 1 & 1 & 1 & 1 & 0 & 1 & 0 & 1 & 1 & 1 & 1 & 1 & 0 & 1 & 1 & 1 & 0 & 1 & 5 & 9 \\
\hline $\begin{array}{l}\text { Bosnia and } \\
\text { Herzegovina }\end{array}$ & 1 & 1 & 1 & 1 & 1 & 1 & 1 & 1 & 1 & 1 & 1 & 1 & 1 & 1 & 1 & 1 & 0 & 1 & 8 & 9 \\
\hline Botswana & 1 & 1 & 1 & 1 & 1 & 1 & 1 & 1 & 1 & 1 & 1 & 1 & 1 & 1 & 1 & 1 & 0 & 0 & 8 & 8 \\
\hline Brazil & 1 & 1 & 1 & 1 & 1 & 1 & 1 & 1 & 1 & 1 & 0 & 1 & 1 & 1 & 1 & 0 & 1 & 1 & 8 & 8 \\
\hline Bulgaria & 1 & 1 & 1 & 1 & 1 & 1 & 1 & 1 & 1 & 1 & 1 & 1 & 1 & 1 & 1 & 1 & 1 & 0 & 9 & 8 \\
\hline Burkina Faso & 1 & 1 & 1 & 1 & 1 & 1 & 1 & 1 & 0 & 1 & 1 & 1 & 1 & 1 & 1 & 1 & 1 & 1 & 8 & 9 \\
\hline Burundi & 1 & 1 & 1 & 1 & 1 & 1 & 1 & 1 & 1 & 0 & 1 & 1 & 1 & 1 & 1 & 1 & 0 & 1 & 8 & 8 \\
\hline Canada & 1 & 1 & 1 & 1 & 0 & 0 & 0 & 0 & 0 & 1 & 1 & 1 & 1 & 1 & 1 & 1 & 0 & 0 & 5 & 6 \\
\hline $\begin{array}{l}\text { Cayman } \\
\text { Islands }\end{array}$ & 1 & 1 & 1 & 1 & 0 & 0 & 1 & 0 & 0 & 0 & 1 & 1 & 0 & 1 & 1 & 1 & 0 & 0 & 5 & 5 \\
\hline Chile & 1 & 1 & 1 & 1 & 0 & 1 & 1 & 1 & 0 & 1 & 1 & 1 & 0 & 1 & 1 & 1 & 1 & 1 & 6 & 9 \\
\hline $\begin{array}{l}\text { China- } \\
\text { People's } \\
\text { Rep. }\end{array}$ & 1 & 1 & 1 & 1 & 0 & 1 & 0 & 1 & 1 & 1 & 1 & 1 & 0 & 1 & 1 & 1 & 0 & 0 & 5 & 8 \\
\hline Colombia & 1 & 1 & 1 & 1 & 1 & 1 & 1 & 1 & 0 & 1 & 1 & 1 & 1 & 1 & 1 & 1 & 1 & 1 & 8 & 9 \\
\hline
\end{tabular}


Table B.1 (Continued)

\begin{tabular}{|c|c|c|c|c|c|c|c|c|c|c|c|c|c|c|c|c|c|c|c|c|}
\hline \multirow[b]{2}{*}{ Country } & \multicolumn{2}{|c|}{ AuditorReq1 } & \multicolumn{2}{|c|}{ AuditorReq2 } & \multicolumn{2}{|c|}{ AuditorReq3 } & \multicolumn{2}{|c|}{ AuditingReq1 } & \multicolumn{2}{|c|}{ AuditingReq2 } & \multicolumn{2}{|c|}{ AuditingReq3 } & \multicolumn{2}{|c|}{ AuditingReq4 } & \multicolumn{2}{|c|}{ AudSupRel1 } & \multicolumn{2}{|c|}{ AudSupRel2 } & \multicolumn{2}{|c|}{ AIS Index } \\
\hline & 2007 & 2012 & 2007 & 2012 & 2007 & 2012 & 2007 & 2012 & 2007 & 2012 & 2007 & 2012 & 2007 & 2012 & 2007 & 2012 & 2007 & 2012 & 2007 & 2012 \\
\hline Costa Rica & 1 & 1 & 1 & 1 & 0 & 1 & 1 & 1 & 1 & 1 & 1 & 1 & 1 & 1 & 1 & 1 & 1 & 0 & 8 & 8 \\
\hline Côte d'Ivoire & 1 & 1 & 1 & 1 & 1 & 1 & 1 & 1 & 0 & 1 & 1 & 1 & 1 & 1 & 1 & 1 & 1 & 1 & 8 & 9 \\
\hline Croatia & 1 & 1 & 1 & 1 & 1 & 1 & 1 & 1 & 1 & 1 & 1 & 1 & 1 & 1 & 1 & 1 & 1 & 1 & 9 & 9 \\
\hline Cyprus & 1 & 1 & 1 & 1 & 0 & 1 & 1 & 1 & 1 & 1 & 1 & 1 & 0 & 1 & 1 & 1 & 1 & 1 & 7 & 9 \\
\hline Denmark & 1 & 1 & 1 & 1 & 1 & 1 & 1 & 1 & 1 & 1 & 1 & 1 & 1 & 1 & 1 & 1 & 1 & 0 & 9 & 8 \\
\hline $\begin{array}{l}\text { Dominican } \\
\text { Republic }\end{array}$ & 1 & 1 & 1 & 1 & 1 & 1 & 1 & 1 & 1 & 0 & 1 & 1 & 1 & 1 & 1 & 1 & 1 & 1 & 9 & 8 \\
\hline Egypt & 1 & 1 & 1 & 1 & 1 & 1 & 1 & 1 & 1 & 1 & 1 & 1 & 1 & 1 & 1 & 1 & 1 & 1 & 9 & 9 \\
\hline El Salvador & 1 & 1 & 1 & 1 & 1 & 0 & 1 & 1 & 1 & 1 & 1 & 1 & 1 & 0 & 1 & 0 & 1 & 0 & 9 & 5 \\
\hline Estonia & 1 & 1 & 1 & 0 & 1 & 1 & 1 & 1 & 1 & 1 & 1 & 1 & 1 & 1 & 1 & 1 & 1 & 1 & 9 & 8 \\
\hline Ethiopia & 1 & 1 & 1 & 1 & 0 & 1 & 1 & 1 & 1 & 1 & 1 & 1 & 0 & 1 & 0 & 1 & 0 & 1 & 5 & 9 \\
\hline Fiji & 1 & 1 & 1 & 1 & 1 & 1 & 1 & 1 & 1 & 0 & 1 & 1 & 1 & 1 & 1 & 1 & 0 & 0 & 8 & 7 \\
\hline Finland & 1 & 1 & 1 & 1 & 0 & 0 & 1 & 0 & 1 & 1 & 1 & 1 & 1 & 1 & 1 & 1 & 0 & 1 & 7 & 7 \\
\hline France & 1 & 1 & 1 & 1 & 1 & 0 & 1 & 1 & 1 & 1 & 1 & 1 & 1 & 1 & 1 & 1 & 0 & 0 & 8 & 7 \\
\hline Germany & 1 & 1 & 1 & 1 & 1 & 1 & 1 & 0 & 0 & 1 & 1 & 1 & 1 & 1 & 1 & 1 & 0 & 0 & 7 & 7 \\
\hline Ghana & 1 & 1 & 1 & 1 & 1 & 1 & 1 & 1 & 1 & 1 & 1 & 1 & 1 & 0 & 1 & 1 & 0 & 1 & 8 & 8 \\
\hline Greece & 1 & 1 & 1 & 1 & 1 & 1 & 1 & 1 & 1 & 1 & 1 & 1 & 1 & 1 & 1 & 0 & 1 & 0 & 9 & 7 \\
\hline Guatemala & 1 & 1 & 1 & 1 & 1 & 1 & 0 & 1 & 0 & 0 & 1 & 1 & 0 & 0 & 1 & 1 & 1 & 1 & 6 & 7 \\
\hline Guernsey & 1 & 1 & 1 & 1 & 0 & 0 & 1 & 1 & 0 & 1 & 1 & 1 & 1 & 1 & 0 & 1 & 0 & 0 & 5 & 7 \\
\hline $\begin{array}{l}\text { Guinea- } \\
\text { Bissau }\end{array}$ & 1 & 1 & 1 & 1 & 1 & 1 & 1 & 1 & 0 & 1 & 1 & 1 & 1 & 1 & 1 & 1 & 1 & 1 & 8 & 9 \\
\hline Guyana & 1 & 1 & 1 & 1 & 1 & 1 & 1 & 1 & 1 & 1 & 1 & 1 & 1 & 1 & 1 & 1 & 1 & 1 & 9 & 9 \\
\hline Honduras & 1 & 1 & 1 & 1 & 1 & 1 & 1 & 1 & 1 & 1 & 1 & 1 & 1 & 1 & 1 & 1 & 0 & 1 & 8 & 9 \\
\hline Hong Kong & 1 & 1 & 1 & 1 & 1 & 1 & 1 & 1 & 0 & 1 & 1 & 1 & 1 & 0 & 1 & 1 & 0 & 0 & 7 & 7 \\
\hline Hungary & 1 & 1 & 1 & 1 & 1 & 1 & 1 & 1 & 1 & 1 & 1 & 1 & 1 & 1 & 1 & 1 & 1 & 1 & 9 & 9 \\
\hline Iceland & 1 & 1 & 1 & 1 & 1 & 1 & 1 & 1 & 1 & 1 & 1 & 1 & 1 & 1 & 1 & 1 & 1 & 1 & 9 & 9 \\
\hline India & 1 & 1 & 1 & 1 & 1 & 1 & 0 & 1 & 1 & 1 & 1 & 1 & 0 & 1 & 1 & 1 & 1 & 1 & 7 & 9 \\
\hline Indonesia & 1 & 1 & 1 & 1 & 1 & 1 & 1 & 1 & 1 & 1 & 1 & 1 & 1 & 1 & 1 & 1 & 0 & 1 & 8 & 9 \\
\hline
\end{tabular}


Table B.1 (Continued)

\begin{tabular}{|c|c|c|c|c|c|c|c|c|c|c|c|c|c|c|c|c|c|c|c|c|}
\hline \multirow[b]{2}{*}{ Country } & \multicolumn{2}{|c|}{ AuditorReq1 } & \multicolumn{2}{|c|}{ AuditorReq2 } & \multicolumn{2}{|c|}{ AuditorReq3 } & \multicolumn{2}{|c|}{ AuditingReq1 } & \multicolumn{2}{|c|}{ AuditingReq2 } & \multicolumn{2}{|c|}{ AuditingReq3 } & \multicolumn{2}{|c|}{ AuditingReq4 } & \multicolumn{2}{|c|}{ AudSupRel1 } & \multicolumn{2}{|c|}{ AudSupRel2 } & \multicolumn{2}{|c|}{ AIS Index } \\
\hline & 2007 & 2012 & 2007 & 2012 & 2007 & 2012 & 2007 & 2012 & 2007 & 2012 & 2007 & 2012 & 2007 & 2012 & 2007 & 2012 & 2007 & 2012 & 2007 & 2012 \\
\hline Ireland & 1 & 1 & 1 & 1 & 1 & 1 & 1 & 1 & 0 & 1 & 1 & 1 & 1 & 1 & 1 & 1 & 1 & 0 & 8 & 8 \\
\hline Isle of Man & 1 & 1 & 1 & 1 & 1 & 0 & 1 & 1 & 1 & 1 & 1 & 1 & 1 & 1 & 1 & 1 & 0 & 1 & 8 & 8 \\
\hline Israel & 1 & 1 & 1 & 1 & 1 & 1 & 1 & 0 & 1 & 1 & 1 & 1 & 1 & 1 & 1 & 0 & 0 & 0 & 8 & 6 \\
\hline Italy & 0 & 1 & 1 & 1 & 1 & 1 & 0 & 1 & 0 & 1 & 1 & 1 & 1 & 1 & 1 & 1 & 0 & 1 & 5 & 9 \\
\hline Jamaica & 1 & 1 & 1 & 1 & 1 & 1 & 1 & 1 & 1 & 1 & 1 & 1 & 1 & 1 & 1 & 1 & 1 & 1 & 9 & 9 \\
\hline Jordan & 1 & 1 & 1 & 1 & 1 & 1 & 1 & 1 & 1 & 1 & 1 & 1 & 1 & 1 & 1 & 1 & 0 & 1 & 8 & 9 \\
\hline Kazakhstan & 1 & 0 & 1 & 0 & 0 & 0 & 1 & 0 & 0 & 1 & 1 & 1 & 1 & 1 & 1 & 1 & 0 & 0 & 6 & 4 \\
\hline Kenya & 1 & 1 & 1 & 1 & 1 & 1 & 1 & 1 & 0 & 1 & 1 & 1 & 1 & 1 & 1 & 1 & 0 & 1 & 7 & 9 \\
\hline $\begin{array}{l}\text { Korea, } \\
\text { Republic of }\end{array}$ & 1 & 1 & 1 & 1 & 0 & 1 & 1 & 1 & 1 & 1 & 1 & 1 & 0 & 0 & 1 & 1 & 1 & 1 & 7 & 8 \\
\hline Kosovo & 1 & 1 & 1 & 1 & 1 & 1 & 1 & 1 & 1 & 1 & 1 & 1 & 1 & 1 & 0 & 1 & 1 & 1 & 8 & 9 \\
\hline Kuwait & 1 & 1 & 1 & 1 & 1 & 1 & 1 & 1 & 1 & 1 & 1 & 1 & 1 & 0 & 1 & 1 & 1 & 1 & 9 & 8 \\
\hline Latvia & 1 & 1 & 1 & 1 & 0 & 0 & 1 & 1 & 1 & 1 & 1 & 1 & 1 & 1 & 1 & 1 & 0 & 0 & 7 & 7 \\
\hline Lebanon & 1 & 1 & 1 & 1 & 1 & 1 & 1 & 1 & 1 & 1 & 1 & 1 & 1 & 1 & 1 & 1 & 1 & 1 & 9 & 9 \\
\hline Lesotho & 1 & 1 & 1 & 1 & 1 & 1 & 1 & 1 & 1 & 0 & 1 & 1 & 1 & 1 & 1 & 1 & 1 & 0 & 9 & 7 \\
\hline Liechtenstein & 1 & 1 & 1 & 1 & 1 & 1 & 1 & 0 & 0 & 1 & 1 & 1 & 1 & 1 & 1 & 1 & 1 & 1 & 8 & 8 \\
\hline Lithuania & 1 & 1 & 1 & 1 & 1 & 1 & 1 & 1 & 1 & 1 & 1 & 1 & 1 & 1 & 1 & 1 & 1 & 1 & 9 & 9 \\
\hline Luxembourg & 1 & 1 & 1 & 1 & 1 & 1 & 1 & 1 & 1 & 1 & 1 & 1 & 1 & 1 & 1 & 1 & 1 & 1 & 9 & 9 \\
\hline Macao & 1 & 1 & 1 & 1 & 1 & 1 & 1 & 1 & 1 & 1 & 1 & 1 & 1 & 1 & 1 & 1 & 0 & 0 & 8 & 8 \\
\hline Malawi & 1 & 1 & 1 & 1 & 0 & 1 & 1 & 1 & 1 & 1 & 1 & 1 & 0 & 1 & 1 & 1 & 0 & 0 & 6 & 8 \\
\hline Malaysia & 1 & 1 & 1 & 1 & 1 & 0 & 1 & 1 & 1 & 1 & 1 & 1 & 1 & 1 & 1 & 1 & 1 & 0 & 9 & 7 \\
\hline Maldives & 1 & 1 & 1 & 1 & 1 & 1 & 1 & 1 & 1 & 1 & 1 & 1 & 0 & 1 & 1 & 1 & 1 & 1 & 8 & 9 \\
\hline Mali & 1 & 1 & 1 & 1 & 1 & 1 & 1 & 1 & 0 & 1 & 1 & 1 & 1 & 1 & 1 & 1 & 1 & 1 & 8 & 9 \\
\hline Malta & 1 & 1 & 1 & 1 & 0 & 1 & 1 & 1 & 1 & 1 & 1 & 1 & 1 & 1 & 1 & 1 & 1 & 1 & 8 & 9 \\
\hline Mauritius & 1 & 1 & 1 & 1 & 1 & 1 & 1 & 1 & 1 & 1 & 1 & 1 & 1 & 1 & 1 & 1 & 1 & 1 & 9 & 9 \\
\hline Mexico & 1 & 1 & 1 & 1 & 1 & 1 & 0 & 0 & 1 & 1 & 1 & 1 & 1 & 1 & 1 & 1 & 1 & 1 & 8 & 8 \\
\hline $\begin{array}{l}\text { Moldova, } \\
\text { Republic of }\end{array}$ & 1 & 1 & 1 & 1 & 1 & 1 & 1 & 1 & 1 & 1 & 1 & 1 & 1 & 1 & 1 & 1 & 1 & 0 & 9 & 8 \\
\hline
\end{tabular}


Table B.1 (Continued)

\begin{tabular}{|c|c|c|c|c|c|c|c|c|c|c|c|c|c|c|c|c|c|c|c|c|}
\hline \multirow[b]{2}{*}{ Country } & \multicolumn{2}{|c|}{ AuditorReq1 } & \multicolumn{2}{|c|}{ AuditorReq2 } & \multicolumn{2}{|c|}{ AuditorReq3 } & \multicolumn{2}{|c|}{ AuditingReq1 } & \multicolumn{2}{|c|}{ AuditingReq2 } & \multicolumn{2}{|c|}{ AuditingReq3 } & \multicolumn{2}{|c|}{ AuditingReq4 } & \multicolumn{2}{|c|}{ AudSupRel1 } & \multicolumn{2}{|c|}{ AudSupRel2 } & \multicolumn{2}{|c|}{ AIS Index } \\
\hline & 2007 & 2012 & 2007 & 2012 & 2007 & 2012 & 2007 & 2012 & 2007 & 2012 & 2007 & 2012 & 2007 & 2012 & 2007 & 2012 & 2007 & 2012 & 2007 & 2012 \\
\hline Morocco & 1 & 1 & 1 & 1 & 1 & 1 & 1 & 1 & 1 & 0 & 1 & 1 & 1 & 1 & 1 & 1 & 0 & 1 & 8 & 8 \\
\hline Mozambique & 1 & 1 & 1 & 1 & 1 & 0 & 1 & 0 & 0 & 1 & 1 & 1 & 1 & 1 & 1 & 1 & 1 & 0 & 8 & 6 \\
\hline Netherlands & 1 & 1 & 1 & 1 & 1 & 1 & 1 & 1 & 0 & 1 & 1 & 1 & 1 & 1 & 1 & 1 & 0 & 1 & 7 & 9 \\
\hline New Zealand & 1 & 1 & 1 & 1 & 1 & 1 & 1 & 1 & 1 & 1 & 1 & 1 & 0 & 1 & 1 & 0 & 0 & 0 & 7 & 7 \\
\hline Nicaragua & 1 & 1 & 1 & 0 & 1 & 1 & 1 & 1 & 1 & 1 & 1 & 1 & 1 & 1 & 1 & 1 & 0 & 1 & 8 & 8 \\
\hline Niger & 1 & 1 & 1 & 1 & 1 & 1 & 1 & 1 & 0 & 1 & 1 & 1 & 1 & 1 & 1 & 1 & 1 & 1 & 8 & 9 \\
\hline Nigeria & 0 & 1 & 0 & 0 & 0 & 1 & 0 & 1 & 0 & 1 & 0 & 1 & 0 & 0 & 0 & 1 & 0 & 0 & 0 & 6 \\
\hline Norway & 1 & 1 & 1 & 1 & 0 & 1 & 1 & 1 & 1 & 1 & 1 & 1 & 1 & 1 & 1 & 1 & 1 & 1 & 8 & 9 \\
\hline Oman & 1 & 1 & 1 & 1 & 1 & 1 & 1 & 1 & 1 & 1 & 1 & 1 & 1 & 1 & 1 & 1 & 1 & 1 & 9 & 9 \\
\hline Pakistan & 1 & 1 & 1 & 1 & 1 & 1 & 1 & 1 & 1 & 1 & 1 & 1 & 1 & 1 & 1 & 1 & 1 & 1 & 9 & 9 \\
\hline Panama & 1 & 1 & 1 & 1 & 1 & 0 & 1 & 1 & 1 & 0 & 1 & 1 & 0 & 0 & 0 & 1 & 1 & 0 & 7 & 5 \\
\hline Peru & 1 & 1 & 0 & 1 & 1 & 1 & 1 & 1 & 1 & 1 & 1 & 1 & 1 & 1 & 1 & 1 & 1 & 1 & 8 & 9 \\
\hline Philippines & 1 & 1 & 1 & 1 & 1 & 1 & 1 & 1 & 0 & 1 & 1 & 1 & 1 & 1 & 1 & 1 & 0 & 1 & 7 & 9 \\
\hline Poland & 1 & 1 & 1 & 1 & 1 & 1 & 1 & 1 & 1 & 0 & 1 & 1 & 1 & 1 & 1 & 1 & 0 & 0 & 8 & 7 \\
\hline Portugal & 1 & 1 & 1 & 1 & 1 & 0 & 1 & 1 & 1 & 1 & 1 & 1 & 1 & 1 & 1 & 1 & 1 & 1 & 9 & 8 \\
\hline Romania & 1 & 1 & 1 & 1 & 0 & 1 & 1 & 1 & 1 & 1 & 1 & 1 & 1 & 1 & 1 & 1 & 1 & 1 & 8 & 9 \\
\hline $\begin{array}{l}\text { Russian } \\
\text { Federation }\end{array}$ & 1 & 1 & 1 & 1 & 1 & 1 & 1 & 0 & 1 & 1 & 1 & 1 & 0 & 0 & 1 & 0 & 0 & 0 & 7 & 5 \\
\hline Senegal & 1 & 1 & 1 & 1 & 1 & 1 & 1 & 1 & 0 & 1 & 1 & 1 & 1 & 1 & 1 & 1 & 1 & 1 & 8 & 9 \\
\hline Seychelles & 1 & 1 & 1 & 1 & 1 & 1 & 1 & 0 & 1 & 1 & 1 & 1 & 1 & 1 & 1 & 1 & 0 & 1 & 8 & 8 \\
\hline Slovakia & 1 & 1 & 0 & 1 & 1 & 1 & 1 & 1 & 1 & 1 & 1 & 1 & 1 & 1 & 1 & 1 & 0 & 0 & 7 & 8 \\
\hline Slovenia & 1 & 1 & 1 & 1 & 1 & 1 & 1 & 1 & 1 & 1 & 1 & 1 & 1 & 1 & 1 & 1 & 1 & 1 & 9 & 9 \\
\hline South Africa & 1 & 1 & 1 & 1 & 1 & 1 & 1 & 1 & 0 & 1 & 1 & 1 & 1 & 1 & 1 & 1 & 1 & 0 & 8 & 8 \\
\hline Spain & 1 & 1 & 1 & 1 & 1 & 0 & 1 & 0 & 1 & 1 & 1 & 1 & 1 & 1 & 1 & 1 & 1 & 1 & 9 & 7 \\
\hline Sri Lanka & 1 & 1 & 1 & 1 & 1 & 1 & 1 & 1 & 1 & 1 & 1 & 1 & 0 & 1 & 1 & 1 & 0 & 1 & 7 & 9 \\
\hline Suriname & 1 & 1 & 1 & 1 & 0 & 0 & 1 & 0 & 0 & 0 & 1 & 1 & 0 & 0 & 0 & 1 & 0 & 0 & 4 & 4 \\
\hline Switzerland & 1 & 1 & 1 & 1 & 1 & 1 & 1 & 1 & 1 & 0 & 1 & 1 & 1 & 1 & 1 & 1 & 1 & 1 & 9 & 8 \\
\hline
\end{tabular}


Table B.1 (Continued)

\begin{tabular}{|c|c|c|c|c|c|c|c|c|c|c|c|c|c|c|c|c|c|c|c|c|}
\hline \multirow[b]{2}{*}{ Country } & \multicolumn{2}{|c|}{ AuditorReq1 } & \multicolumn{2}{|c|}{ AuditorReq2 } & \multicolumn{2}{|c|}{ AuditorReq3 } & \multicolumn{2}{|c|}{ AuditingReq1 } & \multicolumn{2}{|c|}{ AuditingReq2 } & \multicolumn{2}{|c|}{ AuditingReq3 } & \multicolumn{2}{|c|}{ AuditingReq4 } & \multicolumn{2}{|c|}{ AudSupRel1 } & \multicolumn{2}{|c|}{ AudSupRel2 } & \multicolumn{2}{|c|}{ AIS Index } \\
\hline & 2007 & 2012 & 2007 & 2012 & 2007 & 2012 & 2007 & 2012 & 2007 & 2012 & 2007 & 2012 & 2007 & 2012 & 2007 & 2012 & 2007 & 2012 & 2007 & 2012 \\
\hline $\begin{array}{l}\text { Syrian Arab } \\
\text { Republic }\end{array}$ & 1 & 1 & 1 & 1 & 1 & 1 & 1 & 1 & 1 & 1 & 1 & 1 & 1 & 0 & 1 & 1 & 1 & 0 & 9 & 7 \\
\hline Taiwan & 1 & 1 & 1 & 1 & 1 & 0 & 1 & 1 & 1 & 1 & 1 & 1 & 1 & 1 & 1 & 1 & 1 & 1 & 9 & 8 \\
\hline Tajikistan & 1 & 1 & 1 & 1 & 0 & 0 & 1 & 0 & 1 & 1 & 1 & 1 & 0 & 1 & 1 & 1 & 1 & 1 & 7 & 7 \\
\hline $\begin{array}{l}\text { Tanzania, } \\
\text { United } \\
\text { Republic of }\end{array}$ & 1 & 1 & 1 & 1 & 0 & 0 & 1 & 1 & 1 & 1 & 1 & 1 & 1 & 1 & 1 & 1 & 1 & 1 & 8 & 8 \\
\hline Thailand & 1 & 1 & 1 & 1 & 1 & 1 & 1 & 0 & 1 & 1 & 1 & 1 & 1 & 1 & 1 & 1 & 1 & 1 & 9 & 8 \\
\hline Togo & 1 & 1 & 1 & 1 & 1 & 1 & 1 & 1 & 0 & 1 & 1 & 1 & 1 & 1 & 1 & 1 & 1 & 1 & 8 & 9 \\
\hline $\begin{array}{l}\text { Trinidad and } \\
\text { Tobago }\end{array}$ & 1 & 1 & 1 & 1 & 1 & 0 & 1 & 1 & 1 & 1 & 1 & 1 & 0 & 1 & 0 & 1 & 1 & 1 & 7 & 8 \\
\hline Uganda & 1 & 1 & 1 & 1 & 1 & 1 & 1 & 1 & 1 & 1 & 1 & 1 & 1 & 1 & 1 & 1 & 1 & 1 & 9 & 9 \\
\hline $\begin{array}{l}\text { United } \\
\text { Kingdom }\end{array}$ & 1 & 1 & 1 & 1 & 1 & 1 & 1 & 1 & 1 & 1 & 1 & 1 & 1 & 1 & 1 & 1 & 0 & 0 & 8 & 8 \\
\hline $\begin{array}{l}\text { United } \\
\text { States }\end{array}$ & 1 & 1 & 1 & 1 & 1 & 1 & 0 & 0 & 0 & 1 & 0 & 1 & 0 & 1 & 1 & 1 & 1 & 1 & 5 & 8 \\
\hline Uruguay & 1 & 1 & 1 & 1 & 0 & 1 & 1 & 1 & 1 & 1 & 1 & 1 & 0 & 1 & 1 & 1 & 1 & 1 & 7 & 9 \\
\hline Vanuatu & 1 & 1 & 1 & 1 & 0 & 1 & 1 & 1 & 1 & 0 & 1 & 1 & 0 & 1 & 0 & 1 & 0 & 1 & 5 & 8 \\
\hline $\begin{array}{l}\text { Venezuela, } \\
\text { Bolivarian } \\
\text { Republic of }\end{array}$ & 1 & 1 & 1 & 1 & 1 & 1 & 1 & 0 & 0 & 1 & 1 & 1 & 0 & 1 & 1 & 1 & 1 & 1 & 7 & 8 \\
\hline Zimbabwe & 1 & 1 & 1 & 1 & 1 & 0 & 1 & 1 & 1 & 0 & 1 & 1 & 1 & 1 & 1 & 1 & 0 & 1 & 8 & 7 \\
\hline
\end{tabular}

Source: Authors' estimations based on the WB Bank Regulation and Supervision Surveys.

AuditorReq1 provides information on whether an audit by a professional external auditor is required for all commercial banks in the country. AuditorReq2 and AuditorReq3 look at whether

auditors must: 1) obtain a professional certification, and 2) satisfy specific requirements, respectively. AuditingReg(1)-(4) look at the requirements associated with auditing standards, while

AudSup(1)-(2) capture information regarding any kind of active collaboration between the auditors and the supervisors. AlS Index is the degree of external auditors' involvement in supervision. 


\section{APPENDIX C}

\section{Table C.1: Data description}

\begin{tabular}{|c|c|c|}
\hline Variable & Description & Source \\
\hline AIS Index & $\begin{array}{l}\text { Auditors' Involvement in Supervision Index developed in this } \\
\text { paper. See the description provided in Section } 3 \text { for } \\
\text { further details. }\end{array}$ & Authors \\
\hline AIS Index (PCA) & $\begin{array}{l}\text { Auditors' Involvement in Supervision Index developed in this } \\
\text { paper using the weights obtained from the principal component } \\
\text { analysis. }\end{array}$ & Authors \\
\hline $\begin{array}{lrr}\text { Central } \quad \text { Bank } & \text { as } \\
\text { Supervisor } & \text { Index }\end{array}$ & $\begin{array}{l}\text { A dummy variable that takes the value of one if the central bank } \\
\text { is responsible for the supervision of the banking sector. }\end{array}$ & $\begin{array}{l}\text { Masciandaro and Romelli } \\
(2018) \text { and Barth et al. } \\
(2013)\end{array}$ \\
\hline $\begin{array}{l}\Delta \text { Central Bank as } \\
\text { Supervisor Index }\end{array}$ & $\begin{array}{l}\text { A dummy variable equal one if a supervisory reform that } \\
\text { increased the degree of central bank involvement in banking } \\
\text { supervision occurred between } 2007 \text { and } 2012 \text {. }\end{array}$ & $\begin{array}{l}\text { Masciandaro and Romelli } \\
(2018) \text { and Barth et al. } \\
(2013)\end{array}$ \\
\hline $\begin{array}{lrr}\text { Central } & \text { Bank } & \text { as } \\
\text { Financial } & \text { Sector } \\
\text { Supervisor } & \text { Index }\end{array}$ & $\begin{array}{l}\text { An index of the degree of central bank involvement in financial } \\
\text { sector supervision that ranges from } 1 \text { to } 6 \text {. A higher value } \\
\text { indicates a higher concentration of supervisory powers in the } \\
\text { hand of the central bank. The variable takes value } 6 \text { if the central } \\
\text { bank has full responsibilities for the supervision of the entire } \\
\text { financial system, } 5 \text { if banking and securities market supervision } \\
\text { are in the hand of the central bank, } 4 \text { if banking and insurance } \\
\text { sector supervision are in the hand of the central bank, } 3 \text { if the } \\
\text { central bank is only responsible for banking supervision, } 2 \text { if the } \\
\text { central bank is partially responsible for banking supervision, and } \\
1 \text { if the central bank is not involved in supervision. }\end{array}$ & $\begin{array}{l}\text { Masciandaro and Romelli } \\
\text { (2018) }\end{array}$ \\
\hline $\begin{array}{l}\Delta \text { Central Bank as } \\
\text { Financial } \\
\text { Supervisor Index }\end{array}$ & $\begin{array}{l}\text { A variable that captures the change in the degree of central bank } \\
\text { involvement in financial sector supervision between } 2007 \text { and } \\
2012 .\end{array}$ & $\begin{array}{l}\text { Masciandaro and Romelli } \\
\text { (2018) }\end{array}$ \\
\hline Financial crisis & $\begin{array}{l}\text { Dummy variable that takes the value of one if a systemic banking } \\
\text { crisis took place in the country between } 2007 \text { and } 2012 \text {. }\end{array}$ & $\begin{array}{l}\text { Laeven and Valencia } \\
\text { (2013) }\end{array}$ \\
\hline Private Credit to GDP & $\begin{array}{l}\text { Ratio of credit from deposit-taking financial institutions to the } \\
\text { private sector to GDP. }\end{array}$ & $\begin{array}{l}\text { IMF International Financial } \\
\text { Statistics }\end{array}$ \\
\hline GDP per capita & GDP per capita at constant 2005 US dollars. & $\begin{array}{l}\text { World } \quad \text { Development } \\
\text { Indicators }\end{array}$ \\
\hline Supervisory Practices & $\begin{array}{l}\text { Index that measures restrictions imposed on bank activities, } \\
\text { where higher values denote greater restrictions. }\end{array}$ & Cihak et al. (2013) \\
\hline$\Delta$ Supervisory Practices & $\begin{array}{l}\text { Variable that captures the change in the index of Supervisory } \\
\text { Practices between } 2007 \text { and } 2012 \text {. }\end{array}$ & Cihak et al. (2013) \\
\hline Regulatory Quality & $\begin{array}{l}\text { Variable that reflects perceptions of the ability of the } \\
\text { government to formulate and implement sound policies and } \\
\text { regulations that permit and promote private sector development. }\end{array}$ & Kaufmann et al. (2010) \\
\hline Actions Vs Banks & $\begin{array}{l}\text { Number of actions taken by the supervisor in the past } 5 \text { years } \\
(2006-2010) \text { against banks. }\end{array}$ & Barth et al. (2013) \\
\hline Actions Vs Auditors & $\begin{array}{l}\text { Number of actions taken by the supervisor in the past } 5 \text { years } \\
(2006-2010) \text { against auditors. }\end{array}$ & Barth et al. (2013) \\
\hline Big 4 & $\begin{array}{l}\text { Number of the ten biggest banks in your country that are audited } \\
\text { by one of the 'big four' accounting firms (PwC, KPMG, E\&Y, } \\
\text { Deloitte). }\end{array}$ & Barth et al. (2013) \\
\hline $\begin{array}{l}\text { Common Law Legal } \\
\text { Origin }\end{array}$ & $\begin{array}{l}\text { Dummy for Common Law legal roots: } 1=\text { Anglo-Saxon Law; } 0 \\
=\text { non-Anglo-Saxon Law. }\end{array}$ & Authors \\
\hline Public Credit Registry & $\begin{array}{l}\text { Dummy variable that equals } 1 \text { if a public credit registry operates } \\
\text { in the country, } 0 \text { otherwise. }\end{array}$ & Djankov et al. (2007) \\
\hline CBI & $\begin{array}{l}\text { Index of central bank independence that aggregates information } \\
\text { on } 42 \text { criteria of central bank institutional design. }\end{array}$ & Romelli (2018) \\
\hline
\end{tabular}


Table C.2. Descriptive Statistics of $\Delta$ AIS Index

\begin{tabular}{cccccc}
\hline \hline & \multicolumn{2}{c}{ Full sample } & & \multicolumn{2}{c}{ Restricted sample } \\
\cline { 2 - 3 } \cline { 5 - 6 }$\Delta$ AIS Index & Nr. of Obs & Percentage & & Nr. of Obs & Percentage \\
\hline$\leq-2$ & 11 & $10 \%$ & & 5 & $9 \%$ \\
-1 & 18 & $16 \%$ & & 11 & $21 \%$ \\
0 & 41 & $36 \%$ & & 18 & $34 \%$ \\
1 & 27 & $23 \%$ & & 11 & $21 \%$ \\
2 & 10 & $9 \%$ & & 6 & $11 \%$ \\
3 & 4 & $3 \%$ & & 1 & $2 \%$ \\
$\geq 4$ & 4 & $3 \%$ & & 1 & $2 \%$ \\
\hline Sample size & 115 & & 53 & \\
\hline \hline
\end{tabular}

Note: Table shows the distribution of the changes of the AIS Index ( $\triangle$ AIS Index) between 2007 and 2012 for the full sample of countries analyzed in Section 3, as compared to the subset of countries analyzed in Section 4. 


\section{APPENDIX D}

\section{Appendix Table D.1: Drivers of reforms in the AIS index: further robustness checks}

\begin{tabular}{|c|c|c|c|c|c|c|}
\hline & $(1)$ & $(2)$ & (3) & (4) & (5) & $(6)$ \\
\hline AIS Index (2007) & $\begin{array}{c}-0.9795 * * * \\
(0.262)\end{array}$ & $\begin{array}{c}-1.0112 * * * \\
(0.277)\end{array}$ & $\begin{array}{c}-0.9415^{* * *} \\
(0.264)\end{array}$ & $\begin{array}{c}-0.9651 * * * \\
(0.278)\end{array}$ & $\begin{array}{c}-0.8888 * * * \\
(0.263)\end{array}$ & $\begin{array}{c}-0.9189 * * * \\
(0.275)\end{array}$ \\
\hline $\begin{array}{l}\Delta \text { Central Bank as Supervisor } \\
\text { Index }\end{array}$ & $\begin{array}{c}1.3608^{* * *} \\
(0.364)\end{array}$ & & & & & \\
\hline $\begin{array}{l}\Delta \text { Central Bank as Financial } \\
\text { Sector Supervisor Index }\end{array}$ & & $\begin{array}{c}0.2783 * * * \\
(0.105)\end{array}$ & & & & \\
\hline $\begin{array}{l}\triangle \mathrm{CB} \text { as Supervisor Index } x \\
\text { Crisis }\end{array}$ & & & $\begin{array}{c}1.3597 * * * \\
(0.362)\end{array}$ & & & \\
\hline $\begin{array}{l}\Delta \mathrm{CB} \text { as Financial Sector } \\
\text { Supervisor Index } x \text { Crisis }\end{array}$ & & & & $\begin{array}{c}0.3451^{* * *} \\
(0.089)\end{array}$ & & \\
\hline $\begin{array}{l}\Delta \mathrm{CB} \text { as Supervisor Index } x \\
\mathrm{CBI}\end{array}$ & & & & & $\begin{array}{c}1.5847 * * * \\
(0.443)\end{array}$ & \\
\hline $\begin{array}{l}\Delta \mathrm{CB} \text { as Financial Sector } \\
\text { Supervisor Index } x \mathrm{CBI}\end{array}$ & & & & & & $\begin{array}{c}0.3567 * * \\
(0.142)\end{array}$ \\
\hline Financial Crisis & $\begin{array}{c}-0.7075^{*} \\
(0.418)\end{array}$ & $\begin{array}{l}-0.5268 \\
(0.393)\end{array}$ & $\begin{array}{r}-0.6378 \\
(0.421)\end{array}$ & $\begin{array}{r}-0.4817 \\
(0.401)\end{array}$ & $\begin{array}{l}-0.9297 * * \\
(0.435)\end{array}$ & $\begin{array}{c}-0.7630 * \\
(0.402)\end{array}$ \\
\hline$\Delta$ Supervisory practices & $\begin{array}{l}0.2694 \\
(0.174)\end{array}$ & $\begin{array}{c}0.3493 * * \\
(0.175)\end{array}$ & $\begin{array}{l}0.2612 \\
(0.185)\end{array}$ & $\begin{array}{c}0.3666^{*} \\
(0.188)\end{array}$ & $\begin{array}{c}0.3930 * * \\
(0.159)\end{array}$ & $\begin{array}{c}0.4816^{* * *} \\
(0.158)\end{array}$ \\
\hline Pseudo R-squared & 0.20 & 0.21 & 0.19 & 0.21 & 0.21 & 0.22 \\
\hline Observations & 57 & 55 & 53 & 52 & 53 & 52 \\
\hline
\end{tabular}

The dependent variable is the $\triangle$ AIS Index, i.e. the change in the AIS Index between 2007 and 2012. AIS Index (2007) is the degree of external auditors' involvement in supervision in 2007. $\Delta$ Central Bank as Supervisor Index/ Central Bank as Financial Sector Supervisor Index captures the change in the degree of central bank involvement in banking sector and financial sector supervision, respectively between 2007 and 2012. Financial crisis is a dummy that takes the value one for countries experiencing a systemic banking crisis between 2007 and 2012 . $\Delta C B$ as Supervisor Index/ Central Bank as Financial Sector Supervisor Index * Crisis is the interaction term between the change in the degree of central bank involvement in banking and financial sector supervision between 2007 and 2012 and the Financial Crisis dummy. $\Delta C B$ as Supervisor Index/ Central Bank as Financial Sector Supervisor Index * CBI is the interaction term between the change in the degree of central bank involvement in banking and financial sector supervision between 2007 and 2012 and the degree of independence of the country's central bank. $\Delta$ Supervisory Practices captures the changes in supervisory practices adopted by a country in 2012 as compared to 2007 . Robust standard errors in parentheses. $* * *$ denotes significance at a $1 \%$ level, $* *$ denotes significance at a $5 \%$ level, $*$ denotes significance at a $10 \%$ level. 
Appendix Table D.2: Determinants of the level of the AIS index: GMM estimates

Regulatory Quality

Common Law Legal Origin

Public Credit Registry

\section{(1)}

(2)

$\begin{array}{cc}0.1935 & 0.1527 \\ (0.214) & (0.220) \\ 0.7070^{* *} & 1.6351^{* * *} \\ (0.324) & (0.434)\end{array}$

Central Bank as Financial Sector Supervisor Index

Financial Crisis

Private credit to GDP

GDP per capita

(3)

(4)

AIS Index

$0.0088^{*}$

$(0.005)$

$-0.0001$

(0.000)

\begin{tabular}{ccc} 
& $0.3306^{* * *}$ & $0.3663 * * *$ \\
& $(0.067)$ & $(0.064)$ \\
$-0.8966^{* * *}$ & $-0.4969^{*}$ & $-0.5899^{*}$ \\
$(0.327)$ & $(0.297)$ & $(0.317)$ \\
$0.0139 *$ & $0.0097 * *$ & 0.0099 \\
$(0.007)$ & $(0.005)$ & $(0.007)$ \\
-0.0001 & $-0.0001^{*}$ & -0.0001 \\
$(0.000)$ & $(0.000)$ & $(0.000)$ \\
0.2964 & & 0.1808 \\
$(0.799)$ & & $(0.551)$ \\
0.0135 & & -0.9453 \\
$(0.879)$ & & $(0.779)$ \\
$1.2159 * *$ & & -0.2180 \\
$(0.562)$ & & $(0.770)$ \\
& & 131 \\
\hline 133 & 138 & 73 \\
74 & 73 & $11.84[0.755]$ \\
\hline
\end{tabular}

0.1956

(0.214) (0.193)

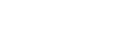

$(0.064)$

$-0.5899 *$

$(0.317)$

0.0099

0.1808

$(0.551)$

$-0.9453$

$(0.779)$

$-0.2180$

(0.770)

\begin{tabular}{lcccc}
\hline Observations & 141 & 133 & 138 & 131 \\
Number of countries & 75 & 74 & 73 & 73 \\
Hansen J test & $7.15[0.894]$ & $9.04[0.912]$ & $6.57[0.923]$ & $11.84[0.755]$ \\
\hline \hline
\end{tabular}

The dependent variable is a restricted version of the AIS Index in 2007 and 2012. Central Bank as Supervisor Index/ Central Bank as Financial Sector Supervisor Index captures the degree of central bank involvement in banking and financial sector supervision in 2011. Financial crisis is a dummy that takes the value one for countries experiencing a systemic banking crisis between 2007 and 2012. Supervisory Practices captures the supervisory practices in a country in 2011. Regulatory Quality captures perceptions of the ability of the government to formulate and implement sound policies and regulations that permit and promote private sector development in 2011. Common Law Legal Origin is a variable for common law countries. Public Credit Registry is a dummy for the presence of public credit registries in the country. The p-value of the Hansen J overidentification test is reported in square brackets. Robust standard errors in parentheses. $* * *$ denotes significance at a $1 \%$ level, $* *$ denotes significance at a $5 \%$ level, $*$ denotes significance at a $10 \%$ level. 
Appendix Table D.3: Drivers of reforms in the AIS index

\begin{tabular}{|c|c|c|c|c|c|c|}
\hline & $(1)$ & $(2)$ & (3) & (4) & $(5)$ & $(6)$ \\
\hline AIS Index (2007) & $\begin{array}{c}-0.7727 * * * \\
(0.237)\end{array}$ & $\begin{array}{c}-0.9879 * * * \\
(0.264)\end{array}$ & $\begin{array}{c}-0.7685^{* * *} \\
(0.237)\end{array}$ & $\begin{array}{c}-0.9841^{* * *} \\
(0.263)\end{array}$ & $\begin{array}{c}-0.8685^{* * *} \\
(0.228)\end{array}$ & $\begin{array}{c}-1.1603 * * * \\
(0.258)\end{array}$ \\
\hline $\begin{array}{l}\Delta \text { Central Bank as Supervisor Index } \\
\text { (Random) }\end{array}$ & $\begin{array}{l}0.2163 \\
(0.307)\end{array}$ & & $\begin{array}{l}0.2079 \\
(0.299)\end{array}$ & & $\begin{array}{l}0.2855 \\
(0.336)\end{array}$ & \\
\hline $\begin{array}{l}\Delta \text { Central Bank as Financial Sector } \\
\text { Supervisor Index (Random) }\end{array}$ & & $\begin{array}{r}-0.0387 \\
(0.133)\end{array}$ & & $\begin{array}{c}-0.0222 \\
(0.139)\end{array}$ & & $\begin{array}{r}-0.0104 \\
(0.214)\end{array}$ \\
\hline Financial Crisis & $\begin{array}{c}-0.8317 \\
(0.558)\end{array}$ & $\begin{array}{c}-0.9911 \\
(0.679)\end{array}$ & $\begin{array}{r}-0.9199 \\
(0.566)\end{array}$ & $\begin{array}{r}-1.1565 \\
(0.707)\end{array}$ & $\begin{array}{r}-0.6500 \\
(0.557)\end{array}$ & $\begin{array}{l}-0.2421 \\
(0.669)\end{array}$ \\
\hline Private credit to GDP & $\begin{array}{l}0.0003 \\
(0.003)\end{array}$ & $\begin{array}{l}0.0011 \\
(0.003)\end{array}$ & $\begin{array}{l}0.0012 \\
(0.003)\end{array}$ & $\begin{array}{l}0.0023 \\
(0.003)\end{array}$ & $\begin{array}{l}0.0009 \\
(0.004)\end{array}$ & $\begin{array}{l}-0.0015 \\
(0.004)\end{array}$ \\
\hline GDP per capita & $\begin{array}{l}0.0001 \\
(0.000)\end{array}$ & $\begin{array}{l}0.0001 \\
(0.000)\end{array}$ & $\begin{array}{l}0.0001 \\
(0.000)\end{array}$ & $\begin{array}{c}0.0001 \\
(0.000)\end{array}$ & $\begin{array}{l}0.0001 \\
(0.000)\end{array}$ & $\begin{array}{l}0.0001 \\
(0.000)\end{array}$ \\
\hline$\Delta$ Supervisory practices & $\begin{array}{l}0.0061 \\
(0.139)\end{array}$ & $\begin{array}{c}0.2955^{*} \\
(0.177)\end{array}$ & $\begin{array}{l}0.0262 \\
(0.141)\end{array}$ & $\begin{array}{c}0.3288 * \\
(0.178)\end{array}$ & $\begin{array}{l}0.1776 \\
(0.188)\end{array}$ & $\begin{array}{l}0.2723 \\
(0.225)\end{array}$ \\
\hline Regulatory Quality & & & $\begin{array}{l}-0.1570 \\
(0.238)\end{array}$ & $\begin{array}{r}-0.2436 \\
(0.293)\end{array}$ & $\begin{array}{c}-0.2940 \\
(0.334)\end{array}$ & $\begin{array}{l}-0.1298 \\
(0.371)\end{array}$ \\
\hline Actions Vs Banks & & & & & $\begin{array}{c}0.0037^{* *} \\
(0.002)\end{array}$ & $\begin{array}{l}-0.0005 \\
(0.001)\end{array}$ \\
\hline Actions Vs Auditors & & & & & $\begin{array}{l}0.0056 \\
(0.014)\end{array}$ & $\begin{array}{c}0.0307 * * * \\
(0.010)\end{array}$ \\
\hline Big4 & & & & & $\begin{array}{l}0.0873 \\
(0.064)\end{array}$ & $\begin{array}{l}0.1115 \\
(0.076)\end{array}$ \\
\hline Common Law Legal Origin & & & & & $\begin{array}{c}0.6556^{*} \\
(0.370)\end{array}$ & $\begin{array}{l}0.6091 \\
(0.465)\end{array}$ \\
\hline Public Credit Registry & & & & & $\begin{array}{l}0.4086 \\
(0.373)\end{array}$ & $\begin{array}{l}0.1385 \\
(0.473)\end{array}$ \\
\hline Pseudo R-squared & 0.18 & 0.20 & 0.18 & 0.21 & 0.24 & 0.26 \\
\hline Observations & 76 & 52 & 76 & 52 & 72 & 48 \\
\hline
\end{tabular}

The dependent variable is $\triangle$ AIS Index, i.e. the change in the AIS Index between 2007 and 2012. AIS Index (2007) is the degree of external auditors' involvement in supervision in 2007. $\Delta$ Central Bank as Supervisor Index (Random)/ Central Bank as Financial Sector Supervisor Index (Random) captures random changes in the degree of central bank involvement in banking sector and financial sector supervision, respectively between 2007 and 2012. Financial crisis is a dummy that takes the value one for countries experiencing a systemic banking crisis between 2007 and 2012 . $\Delta$ Supervisory Practices captures the changes in supervisory practices adopted by a country in 2012 as compared to 2007. Regulatory Quality captures perceptions of the ability of the government to formulate and implement sound policies and regulations that permit and promote private sector development. Actions vs Banks/Auditors provides information on the number of actions that have been taken by the supervisor in the period 2006-2010 against banks/auditors. Big4 is a measure of the number of the ten biggest banks supervised by the big four auditing companies in the country. Common Law Legal Origin is a variable for common law countries. Public Credit Registry is a dummy for the presence of public credit registries in the country. Robust standard errors in parentheses. ${ }^{* *}$ denotes significance at a $1 \%$ level, ${ }^{* *}$ denotes significance at a $5 \%$ level, $*$ denotes significance at a $10 \%$ level. 